\title{
Sources of streamflow along a headwater catchment elevational gradient
}

\author{
Rory M. Cowie ${ }^{1}$, John F. Knowles ${ }^{1}$, Kelsey R. Dailey ${ }^{1}$, Mark W. Williams ${ }^{1,2}$ \\ T. Joseph Mills ${ }^{1}$, Noah P. Molotch ${ }^{1,2,3}$ \\ ${ }^{1}$ Institute of Arctic and Alpine Research, Boulder, CO 80309 USA \\ ${ }^{2}$ Department of Geography, University of Colorado, Boulder, CO, 80309 USA \\ ${ }^{3}$ Jet Propulsion Laboratory, California Institute of Technology, Pasadena, CA, 91109 USA
}

\author{
Corresponding author Address: \\ Dr. Rory M. Cowie \\ INSTAAR, UCB 450 \\ University of Colorado \\ Boulder, CO, 80309 USA
}

Page 1 of 54

(C) 2017. This manuscript version is made available under the Elsevier user license http://www.elsevier.com/open-access/userlicense/1.0/ 


\begin{abstract}
We used End-Member Mixing Analysis (EMMA) to investigate the spatiotemporal variability of source water contributions to streamflow generation from three headwater catchments that span a precipitation and ecosystem type gradient across $\sim 1500$ m elevation in the Colorado Front Range, USA. We additionally characterized the magnitude and type (rain versus snow) of precipitation and the resulting hydrologic response of surface and subsurface waters to this precipitation variability. The three catchments were representative of the montane rain-snow transition zone (snow was 39\% of total precipitation; $\sigma($ standard deviation $)=10 \%)$, the subalpine zone $(69 \%$ snow; $\sigma=$ $5 \%$ ), and the alpine zone ( $84 \%$ snow; $\sigma=10 \%$ ). All three catchments were identified as three end-member systems with their respective source waters being groundwater, snow precipitation or melt, rain (montane and subalpine only), and subsurface water from talus slopes (alpine only). Mean annual groundwater contributions were greater in forested catchments $(28 \% ; \sigma=6 \%$ in the montane, $31 \% ; \sigma=8 \%$ in the subalpine) than in the alpine $(19 \% ; \sigma=5 \%)$ catchment. Snow-derived water contributions to streamflow were inversely related to groundwater and increased but became less variable with elevation from $46 \%(\sigma=15 \%)$ in the montane zone to $58 \%(\sigma=12 \%)$ in the subalpine and $61 \%(\sigma$ $=7 \%)$ in the alpine. Rain was $27 \%(\sigma=8 \%)$ of discharge in the montane and $11 \%(\sigma=$ $4 \%)$ in the subalpine, while talus waters made up the final $21 \%(\sigma=12 \%)$ of streamflow in the alpine. Our results suggest that subsurface source waters (groundwater and talus water) that are influenced by the timing, magnitude, and type of recharge and by the storage capabilities of the subsurface may be the most sensitive to climate variability at
\end{abstract}


higher elevations. In contrast, the proportion of rain versus snow was the primary control on source water variability at lower elevations.

Index terms and Keywords: mountain hydrology; groundwater; end-member mixing analysis; surface and groundwater interaction; streamflow generation; rain/snow transition; Rocky Mountains; Colorado Front Range

\section{Introduction}

The hydrology of mountain regions around the world is dominated by snowmelt runoff, which is slowly released to rivers throughout the melt season [Viviroli et al., 2007]. Climate models predict rising air temperatures in the next few decades [IPCC, 2013], resulting in decreased annual snowpack, earlier onset of snowmelt, and increased evaporation [Hamlet et al., 2005; Stewart et al., 2005; Pielke et al., 2005; Clow, 2010]. Some of the most pronounced hydrological changes are forecasted for lower elevations, where rising air temperatures are predicted to increase the seasonal freezing elevation [Ashfaq et al., 2013], leading to increased rain versus snow precipitation [Knowles et al., 2006; Nolin and Daly, 2006; Bavay et al., 2009] and an overall reduction in mean streamflow [Berghuijs et al., 2014]. Conversely, snowfall amounts at higher elevations that experience lower air temperatures may be less sensitive to air temperature increases or may even experience increased snowfall due to higher moisture availability in the future [Adam et al., 2009; Stewart, 2009; Rasmussen et al., 2012]. Additionally, wind speeds are decreasing relatively faster at higher compared to lower elevations, and the subsequent atmospheric demand reductions may result in increased annual streamflow 
from higher elevation headwater catchments [McVicar et al., 2010; Luce et al., 2013].

The combination of these shifts in seasonality and the variable changes in total runoff that are predicted for different elevations are likely to have consequences for future water availability, increasing the challenges for management of water resources originating in mountainous areas [Viviroli et al., 2011; Finger et al., 2012].

An often under-addressed question in snowmelt-dominated mountain watersheds is the role that groundwater plays in streamflow generation. Although recent efforts have identified baseflow patterns (groundwater storage and/or other delayed sources of streamflow) based on regionally derived climatic and physiographic characteristics [Beck et al., 2013], often little is known about mountain aquifers at the catchment scale because they commonly involve structurally complicated crystalline rocks, substantial head gradients (ground slope angles $10-40^{\circ}$ ), and dramatically fluctuating recharge that is driven by seasonal snowmelt [Liu et al., 2004; Manning and Caine, 2007]. Moreover, land surface conditions such as vegetation structure, catchment shape, and directional orientation (aspect ratio) can significantly alter hydrologic processes from the hillslope to the headwater basin scale [Hinckley et al., 2012; Fang et al., 2013], and the structure of the subsurface can also play a significant role in surface-groundwater interactions [Jin et al., 2012]. Since groundwater flow occurs primarily through rock fractures in mountain catchments, the effectiveness of the classic porous medium approach for understanding surface-groundwater interactions is reduced [Hazen et al., 2002], although recent advances in geophysical techniques have been used to better quantify subsurface characteristics influencing groundwater flow [Befus et al., 2011; Leopold et al., 2013a; 2013b; Olyphant et al., 2016]. Finally, due to difficult and often limited access, high- 
elevation catchment hydrology studies often lack the necessary infrastructure (i.e. wells) to adequately access, sample, and/or quantify groundwater resources [Manning and Caine, 2007; Hood and Hayashi, 2015].

Recent studies in mountain areas have established that groundwater storage and flow may be more important than previously thought [Hood and Hayashi, 2015]. Specifically, significant groundwater contributions to streamflow from the alpine areas have been identified from several global mountain ranges including the Himalayan region [Andermann et al., 2012; Williams et al., 2016, Wilson et al., 2016], the Cordillera Blanca of Peru [Baraer et al., 2015; Gordon et al., 2015], and the Rocky Mountains of North America [Clow et al., 2003, Liu et al., 2004; Jepsen et al., 2012; Jin et al., 2012; Fang et al., 2013; Perrot et al., 2014; Spencer et al., 2014]. However, groundwater recharge dynamics are relatively absent from this body of work, particularly as relates to the seasonality of precipitation and catchment storage dynamics [Ajami et al., 2011] that can be directly impacted by climatological changes [e.g. Molotch et al., 2008; Tague and Grant, 2009; Green et al., 2011]. Notwithstanding, it has been hypothesized that increased rain/snow ratios, an earlier onset of spring, and/or decreased snowpack could decrease global mountain block groundwater recharge [Earman et al., 2006; Meixner et al., 2016].

Hydrologic mixing models parameterized with naturally occurring tracers help to identify various sources of water contributing to streamflow. Specifically, mixing models provide a unique way to address the interactions between the specific climate drivers of air temperature and precipitation, as well as the physical landscape controls of groundwater storage on streamflow generation in mountain regions. Additionally, 
hydrologic mixing model results can be further used to perform hydrograph separation using End-Member Mixing Analysis (EMMA) [Christophersen and Hooper, 1992; Hooper, 2001; 2003]. Several key papers on the use of mixing models and EMMA are summarized in Table 1, and include examples of the application of EMMA to identify streamflow source waters in high elevation alpine [e.g. Liu et al., 2004; Gordon et al., 2015] and forested watersheds [e.g. James and Roulet, 2006; Liu et al., 2008; Jin et al., 2012] in mountain ranges around the world. However, there have been few hydrologic mixing model studies that compare results across multiple well-instrumented, headwater catchments from the same watershed, particularly that span the rain-snow transition and/or the forest-tundra ecotone. A spatiotemporal comparison between independent headwater catchments that are linked by regional geologic and climatological similarities, such as that provided by this work, will enhance our ability to scale predictions of streamflow generation from hydrologically important mountainous areas in response to changes in climate.

This study investigates the spatiotemporal variability in source water contributions to streamflow generation from three different headwater catchments that span a precipitation and ecosystem type gradient over 1500 m elevation in the Colorado Front Range, USA. The key study objectives were to: (1) calculate changes in the magnitude and type (rain versus snow) of precipitation with elevation, in order to (2) identify the physical hydrologic response of surface and subsurface waters to the variability in precipitation inputs, and (3) quantify the resulting spatiotemporal variability in source water contributions to streamflow using a hydrologic mixing model (EMMA) unique to each catchment. This research will improve understanding of the hydrologic 
impacts of source water variability (via input, storage, and timing) at the catchment scale, which has important implications for understanding the sensitivity of mountain streamflow to both warming climate and shifting precipitation regimes.

$<$ Table 1 here please >

\section{Study Area}

This study focused on three headwater catchments along an elevational gradient (2446-4084 m asl) within the Boulder Creek Watershed, Colorado, USA. The Boulder Creek Watershed (BCW) is $160 \mathrm{~km}^{2}$ in area and drains the Colorado Front Range from the Continental Divide (4120 m) to the eastern plains (1480 m) (Figure 1a). The three catchments examined in this study were Green Lake 4 (GL4), Como Creek (CC), and Gordon Gulch (GG). The Niwot Ridge Long Term Ecological Research (NWT-LTER) program in the GL4 and CC catchments has collected long-term data, while the GG catchment was instrumented in 2009 as part of the Boulder Creek Critical Zone Observatory (BC-CZO). The three study areas encompass three climatic zones: alpine (GL4), subalpine (CC), and montane (GG) (Table 2). Relative to long-term (1980-2010) precipitation records from the middle elevation $\mathrm{CC}$ catchment, the three years included in this study represent average (100\% in 2010), above average (110\% in 2011), and below average (93\% in 2012) precipitation magnitudes.

$<$ Figure 1 here please >

The bedrock underlying all three catchments is similar and is composed of Precambrian crystalline rock, primarily granodiorite. Nearly equal percentages of gneiss and schist are present in the alpine, compared to the montane zone where gneiss becomes predominant [Braddock and Cole, 1990]. The alpine GL4 catchment is an east-facing 
glacial valley in the Colorado Front Range (Figure 1b). The catchment is approximately 225 ha in area, and the elevation ranges from $4084 \mathrm{~m}$ at the Continental Divide to $3515 \mathrm{~m}$ at the outlet of GL4. The basin area is composed of $29 \%$ exposed bedrock, $33 \%$ talus, $29 \%$ vegetated soils, 4\% the Arikaree glacier, and 5\% paternoster lakes (Green Lake 4 and Green Lake 5) [Erickson et al., 2005]. The GL4 catchment is a typical alpine headwater catchment in the Colorado Front Range where active and inactive rock glaciers may be indicative of sporadic permafrost [Janke, 2005].

The CC catchment is 536 ha in area and originates just to the north and east of Green Lakes Valley on the southeast flank of Niwot Ridge, approximately $8 \mathrm{~km}$ east of the Continental Divide at an elevation of 2900-3660 m (Figure 1c). Forests cover 70\% of the catchment and $30 \%$ is alpine tundra. The catchment has no remaining periglacial features such as rock glaciers, but was glaciated during the Pleistocene and the lower half of the $\mathrm{CC}$ catchment resides primarily on the Arapaho moraine. Soil depth has a mean of $60 \mathrm{~cm}$, a maximum of about $200 \mathrm{~cm}$, and is generally thicker in areas overlying moraine materials [Lewis and Grant, 1979]. The forest stand age is approximately one hundred years with minimal human disturbance during that time [Lewis and Grant, 1979]. The forest is currently dominated by Engelmann spruce (Picea engelmannii), subalpine fir (Abies lasiocarpa), limber pine (Pinus flexilis), lodgepole pine (Pinus contorta), and aspen (Populus tremuloides).

The GG catchment is 95 ha and is in mixed conifer forest from $2588-2737 \mathrm{~m}$ elevation (Figure 1d). The GG catchment lies within the low-relief post-Laramide surface below the extent of Pleistocene glaciers [Bradley, 1987]. Atypical for this type of rolling upland surface, GG contains steep topography with many bedrock exposures of 
Precambrian granites, gneisses and schists. Shallow seismic refraction suggests that unconsolidated materials are generally less than $1 \mathrm{~m}$ thick, while weathered bedrock profiles extend to depths of 11 to $15 \mathrm{~m}$ [Befus, 2010]. Soil depth averaged $79 \mathrm{~cm}$ in soil pits $(n=7)$ on the north and south facing hillslopes and $168 \mathrm{~cm}$ in soil pits $(n=2)$ in riparian areas at the bottom of the catchment near the stream channel [Eilers et al., 2012]. The GG catchment is a predominantly west-to-east drainage with north aspect slopes dominated by Lodgepole pine (Pinus contorta), Rocky Mountain Douglas-fir (Psuedotsuga menziesii var. glauca), and Colorado blue spruce (Picea pungens). The south aspect slopes are an open mosaic of Ponderosa pine (Pinus ponderosa) and Rocky Mountain juniper (Juniperus scopulorum).

\section{Methods}

Physical parameters of climate (air temperature and precipitation) (Section 3.1) and hydrology (surface water, groundwater, rock glacier outflow, soil water, talus water, snowpack, snowmelt) (Section 3.2-3.4) were measured at multiple locations across the study areas to characterize annual water fluxes at the catchment scale. Additionally, the chemical composition (solutes and stable isotopes) of streamflow and potential contributing source waters (e.g. rain, snow, snow melt, groundwater, soil water, rock glacier outflow water, subsurface talus flows) were measured at regular intervals throughout the study to identify source waters and flowpaths (Sections 3.5-3.6).

\subsection{Climate: Air Temperature and Precipitation}

At GL4, the maximum and minimum daily air temperature were measured at the D-1 alpine tundra site $(3739 \mathrm{~m}$ ) (Figure 1b), which is located on the northern edge of Green Lakes Valley, $2.6 \mathrm{~km}$ from the Continental Divide. At CC, air temperature was 
measured at the C-1 site (3021 m) (Figure 1c). Both D-1 and C-1 are part of a long-term meteorological study that has recorded continuous meteorological data since the 1950 s [Williams et al., 1996]. Air temperature at GG was measured at the B-1 station (2621 m) located $2 \mathrm{~km}$ northeast of GG. The air temperature record at B-1 was unavailable from January 2011 to June 2012 so no annual statistics were calculated for GG during that period. Data from these sites can be downloaded through the NWT-LTER database (http://culter.colorado.edu/NWT).

Daily precipitation for GL4 was measured at the D-1 climate station using a Belfort 5-780 weighing-bucket gauge with an Alter wind shield encircled by a Wyomingsnow fence [Kittel et al., 2015]. Additional precipitation measurements for the GL4 catchment have been recorded since 1982 at the base of the Arikaree Glacier (3814 m) on a small moraine on the valley floor at the head of the catchment (Figure 1). Based on a 30 -year record of 1 October to 30 June precipitation, the Arikaree site received an average of $136 \%\left(R^{2}=0.78\right)$ of the total precipitation recorded at $D-1$. Due to inherent spatial variability of snow accumulation across the GL4 catchment [see Erickson et al., 2005], a correction factor of 1.18 (half the difference between the D-1 and Arikaree measured precipitation) was applied to the D-1 precipitation totals during this time to more accurately represent the GL4 inputs [Williams et al., 1998]. During 1 July to 30 September, precipitation at D-1 was used uncorrected to represent GL4 summer precipitation following the protocol of Williams et al. [1998]. Precipitation for CC was measured at several sites using a combination of shielded gauges and applying the hypsometric approach as detailed in Knowles et al. [2015]. Daily precipitation for GG was measured at the National Atmospheric Deposition Program (NADP) Sugarloaf site 
(CO94; $2524 \mathrm{~m}$ ) located $3 \mathrm{~km}$ to the southwest of GG (Figure 1d). The Sugarloaf NADP site uses an ETI NOAH IV gauge with an Alter shield to minimize undercatch. Water balance research conducted in CC for 2008-2012 produced an estimated systematic uncertainty in annual precipitation measurements of 3.5\% [Knowles et al., 2015]. Given the similarity of instruments across all catchments, this uncertainty value was applied to all annual precipitation calculations.

Previous work by Klos et al. [2014] identified the importance of classifying precipitation type in the Rocky Mountains, especially during spring and fall when both rain and snow events are probable. Consequently, precipitation was classified as either snow, mixed, or rain based on air temperature records. Although Marks et al. [2013] found phase partitioning to generally occur at air temperatures between $0^{\circ} \mathrm{C}$ and $1{ }^{\circ} \mathrm{C}$, their study sites were located between 1000 and 2200 m elevation. Since our study sites were all located above 2500 m elevation, we followed Dai [2008] who reported that the half-frequency (equal likelihood) of snow versus rain occurs at $1.8^{\circ} \mathrm{C}$ at high elevations (air pressure at ground surface below $\sim 750 \mathrm{hPa}$ ) globally. The mean hourly air pressure at the lowest elevation climate station (B-1) in this study was $<750 \mathrm{hPa}$ between 2010 2012; therefore, precipitation was classified as rain if the mean hourly air temperature was above $1.8^{\circ} \mathrm{C}$ throughout the duration of the precipitation event (period of continuous precipitation). Conversely, if the air temperature was less than $1.8^{\circ} \mathrm{C}$ throughout the event, the precipitation was classified as snow, and when temperatures crossed the $1.8^{\circ} \mathrm{C}$ threshold during a single event the precipitation was classified as mixed. To constrain the uncertainty of the $1.8^{\circ} \mathrm{C}$ air temperature threshold, precipitation classification was also performed using a $1.0^{\circ} \mathrm{C}$ threshold. The lower air temperature threshold decreased 
calculated annual snowfall by $2.3 \%$ at the lowest elevation site where higher winter air temperatures would make phase change most probable. We interpret this as the maximum uncertainty associated with our precipitation classification threshold since the other higher elevation sites experience these threshold air temperatures less frequently.

The precipitation chemistry was analyzed as weekly composites based on NADP measurement sites near each study catchment (CO02, CO90, and CO94; see http://nadp.sws.uiuc.edu/data/sites); subsets were retained for analysis of stable water isotopes. The NADP collection method utilizes an automated wet precipitation sampler where the sample container lid is only open when precipitation is occurring, minimizing evaporation or contamination from dry deposition during the weekly sampling interval. Additionally, during weeks of seasonally transitional weather, when both rain and snow were known to be collected in the same composite sample (or mixed precipitation was recorded), the precipitation chemistry was excluded from the independent analysis of rain and snow as potential source waters.

\subsection{Discharge}

Water level was measured at the outlet of each catchment using a stream gauge with a continuously recording vented pressure transducer. The water level was converted to volumetric discharges by empirical rating curves that were constructed each year using manual measurements taken approximately weekly over the full range of the hydrograph. The flow records for been collected since 1982 at GL4 and since 2003 at CC and are available at http://niwot.colorado.edu/exec/.extracttoolA?g14disch.nc. The flow record began in 2010 at GG and is available at http://criticalzone.org/boulder/data/dataset/2919/. 
We calculated annual water year (1 October to 30 September) flow in each catchment by summing recorded mean daily streamflow.

Due to extensive freezing in the stilling well at $\mathrm{CC}$, the transducer was installed each year around 1 April and removed in November. To account for flows not recorded by the transducer, a baseflow value of $3 \mathrm{~L} \mathrm{~s}^{-1}$ was applied during the winter months (day of year (DOY) 315 to DOY 115), which amounted to $45 \%$ of the year, but only an average of $4 \%$ of the total annual flow in CC [Knowles et al., 2015]. The value was chosen based on late season (baseflow) transducer values, occasional manual measurements, and earlier work that reported baseflow of $3 \mathrm{~L} \mathrm{~s}^{-1}$ using a flume at a nearby location on Como Creek [Lewis and Grant, 1979]. When the transducer record began after DOY 115 or ended prior to DOY 315, daily discharge values were linearly interpolated to reach assumed baseflow values at the dates specified above. At GL4 and GG, the pressure transducers could record year-round and missing data were infilled using linear interpolation. Following the results of Knowles et al. [2015], an estimated systematic uncertainty in annual discharge of $15 \%$ was applied to specific annual discharge calculations.

\subsection{Snow and Snowmelt}

The snowpack was sampled approximately weekly at C-1, Soddie, and Saddle sites (Figure 1) for chemical content, snow water equivalent (SWE), and stable isotopes of water via snow pits following the protocols of Williams et al. [1999; 2009]. The snow pits were excavated and refilled weekly with each successive pit located further along a longitudinal transect to avoid contamination or physical manipulation of snowpack characteristics. Additionally, annual snow surveys were conducted in the GL4 catchment 
each year near maximum accumulation following protocols of Erickson et al. [2005], which included five snow pits spatially distributed across the catchment (Figure 1b). The chemical and isotopic content of the snowpack are thus reported for GL4 and CC at maximum accumulation when the maximum loading of solutes stored in the seasonal snowpack occurs [Williams et al., 2009]. The depth-integrated, volume-weighted mean snowpack concentrations of solutes and stable water isotopes were determined for each duplicate snow sample as in Williams and Melack [1991a; 1991b] and Williams et al. [1996; 1999]. The snowpack at GG is intermittent and does not necessarily reach a maximum accumulation at the end of season. Therefore, snow chemical composition was generated by calculating the volume-weighted mean concentration of all snowfall events collected at the Sugarloaf NADP site (CO94).

Snowmelt was collected before contact with the ground at the Saddle (for GL4) and Soddie (for CC) sites (Figure 1) and analyzed for solutes and stable water isotopes following the protocols of Williams et al. [2009]. Snowmelt water flowed by gravity from the snow lysimeters into bottles collected as grab samples approximately daily during the melt season. There was no snowmelt chemistry at GG due to the lack of a consistent snowpack.

\subsection{Surface, Groundwater, Talus and Soil Water Sampling}

Stream samples were collected as grab samples following the protocol of Williams et al. [2009]. Samples were collected on a weekly basis at the outlets of the GL4, CC, and GG catchments during the ice-free season and approximately monthly during the remainder of the year. At GL4, additional surface flows were collected from the outflow of a rock glacier, while talus water was collected as surface water grab 
samples when water was available (Figure 1b). Soil water was collected in GL4 from two sets of two co-located zero tension lysimeters. Soil water was also collected in CC from zero tension lysimeters, one of which was located at the Soddie and three of which were co-located with groundwater wells near C-1 (Figure 1c).

Groundwater was sampled weekly during ice-free months and monthly during the rest of the year from four co-located observation wells located at the Saddle site between CC and GL4 (shown in Figure 1c). The wells were installed in 2005 and consist of piezometers screened at the bottom $1.5 \mathrm{~m}$ with total depths of 6.3-8.4 m. Four additional co-located groundwater wells were installed in fall 2010 near C-1 in CC, including three medium depth (6-8 m) wells (C1SO1, 2, and 4) and one deep well (C1SWdeep) screened from 22 to $28 \mathrm{~m}$. The sampled wells in GG were installed in fall 2010 and included two deep wells (screened from 8-18 m) located on the north (Well 1) and south (Well 6) facing slopes of the upper catchment and one shallow well (Well 2, screened from 1.4-4.5 m) located in a meadow adjacent to the stream channel. Sampling of all wells was performed with a $1 \mathrm{~m}$ teflon bailer to minimize chemical contamination after purging three well volumes, and then followed the protocol for surface water collection. Depth to groundwater was measured in each well at the time of sample collection, which provided a time series of groundwater level fluctuations from the time of installation until the end of the study period. Additionally, the wells at GG were installed with pressure transducers that provided continuous records of groundwater level starting in February 2011.

\subsection{Laboratory Analyses}


All precipitation and water samples were analyzed for $\mathrm{pH}$, acid-neutralizing capacity (ANC), specific conductance, $\mathrm{NH}_{4}{ }^{+}, \mathrm{Ca}^{2+}, \mathrm{Na}^{+}, \mathrm{Mg}^{2+}, \mathrm{K}^{+}, \mathrm{Cl}^{-}, \mathrm{NO}_{3}{ }^{-}, \mathrm{SO}_{4}{ }^{2-}, \mathrm{Si}$, DOC, dissolved organic nitrogen (DON) and total dissolved nitrogen (TDN) at the Kiowa Environmental Chemistry Laboratory in Boulder, CO. Detection limits and instrumentation are as presented in Williams et al. [2009]; in general detection limits for all solutes were less than $1 \mu \mathrm{eq} \mathrm{L}^{-1}$. Samples were also analyzed for deuterium (D) and ${ }^{18}$ O using an L1102-i Isotopic Liquid Water Analyzer (Picarro Inc., Santa Clara, CA, USA). Isotopic compositions are expressed as a $\delta$ (per mil) ratio of the sample to the Vienna Standard Mean Ocean Water (V-SMOW), as shown for ${ }^{18} \mathrm{O}$ :

$\delta^{18} \mathrm{O}=\frac{\left({ }^{18} \mathrm{O} /{ }^{16} \mathrm{O}\right) \text { sample }-\left({ }^{18} \mathrm{O} /{ }^{16} \mathrm{O}\right) \text { VSMOW }}{\left({ }^{18} \mathrm{O} /{ }^{16} \mathrm{O}\right) \text { VSMOW }} \times 1000$ (Equation 1)

The precision for $\delta^{18} \mathrm{O}$ was $\pm 0.05 \%$ and for $\mathrm{D}$ was $\pm 0.1 \%$.

\subsection{Hydrograph Separation with End-Member Mixing Analysis}

End-member mixing analysis (EMMA) is a commonly applied method to identify and quantify the dominant runoff-producing source waters [Barthold et al., 2011]. For this study, the diagnostic tools of mixing models [Hooper, 2003] were used in combination with tracer-based EMMA [Christophersen et al., 1990; Christophersen and Hooper, 1992] to identify the most important source waters contributing to streamflow in each catchment. Conservative tracers and the number of end-members that contributed to discharge were identified from geochemical and isotopic data from each stream, not from the end-member samples. Thus no a priori information about the end-member population was needed [Frisbee et al., 2011]. Following the approach of Hooper [2003], a principal component analysis (PCA) was performed to determine the potential end-members rather than using a priori assumptions. The purpose of PCA was to identify a small number of 
components (eigenvectors) that explain a substantial amount of the variation of original variables (geochemical and isotopic tracer values) resulting in a lower dimensional mixing space that explains most of the variation. The PCA results were used to re-project the stream samples and potential end-members into a mixing subspace [Liu et al., 2008] and apply EMMA.

Two main criteria were used to select tracers and choose the dimension of the mixing subspace. First, conservative tracers were determined by plotting the residuals (the difference between original tracer concentration and projected tracer concentration into the U-space, each axis of which is defined by a principle component from the PCA) against the original tracer concentrations. A lack of correlation (considered to be a linear regression model with $R^{2} \leq 0.2$ ) between these residuals and measured concentrations indicates that the tracer behavior is predictable and therefore conservative [Hooper, 2003; Williams et al., 2016]. Additionally, the absolute values of the residuals were evaluated with the relative root mean square error (RRMSE), where RRMSE < 5\% was used to indicate appropriate tracers [Hooper, 2003; Ali et al., 2010]. The RRMSE indicates how "noisy" the data cloud is in the reference mixing space [Ali et al., 2010], with a larger RRMSE indicative of explaining less of the variability in stream water chemistry.

Tracer concentrations in potential end-members were standardized (mean $=0$, standard deviation $=1$ ) using the mean and standard deviation of streamflow samples and projected using the same eigenvectors. From the output of the PCA, the product of the data matrix and its transpose is the eigenvector that forms the geometrical coordinates of the U-space. The sum of the eigenvalues equals the amount of variance explained by the corresponding end-member. The number of end-members was determined as one more 
than the number of eigenvectors required to explain $>90 \%$ of the variance in the data [Christophersen and Hooper, 1992]. All measurable types of potential runoff generating source waters including multiple groundwater wells, soil and snowmelt lysimeters, snowpack, rain and snow precipitation, and subsurface flows emerging from talus slopes and a rock glacier, were treated independently as potential source waters and plotted in the mixing space defined by the stream tracer PCA.

\subsection{Interpretation of End-Member Mixing Diagrams and Uncertainty Analysis}

An appropriate set of end-members will be chemically distinct from stream samples and other selected end-members, bound most stream samples in U-space, and have less temporal variability than observed stream chemistry [Hooper, 2001; Liu et al., 2004; Dailey, 2016]. When multiple end-members were projected in clusters from which more than one end-member met the above-mentioned criteria for selection, a quantitative approach was used to choose the most appropriate one. End-members were selected from clusters by evaluating the Euclidean distance, or the distance between the projected and original end-member concentrations:

$d_{j}=\left\|b_{j} \quad b_{j}^{*}\right\|$

(Equation 2)

$b_{j}^{*}=b_{j} V^{T}\left(V V^{T}\right){ }^{1} V$

(Equation 3)

where $b$ is the end-member, $j$ is the tracer, and $d_{j}$ is the Euclidean distance between the original $\left(b_{j}\right)$ and projected $\left(b_{j}^{*}\right)$ end-member tracer concentration using the Eigenvector $V$ [Christophersen and Hooper, 1992; Liu et al., 2008]. The Euclidean distance was divided by the original median end-member tracer concentration and expressed as a percentage that represents the distance, with shorter distances indicative of a better fit of the endmember in EMMA [Liu et al., 2008]. In this way, U-space projections were substituted 
for hydrologic mixing model tracer concentrations, and the proportional contribution to streamflow was calculated as the distance between streamflow samples and each endmember [Williams et al., 2016].

The relative contributions of end-members to streamflow were expressed as a fraction of the total streamflow on each sampling date and contributions were linearly interpolated between sampling events to enable continuous hydrograph separation. To further constrain the uncertainty associated with each tracer and its subsequent effect on source water contribution, separated hydrographs were generated using the median and interquartile range (25\% to $75 \%$ ) of values for each end-member. Accordingly, two endmembers were held constant at the median value while the third tracer was allowed to vary along the interquartile range; this exercise was repeated for all three end-members. The resulting percent contribution values were then multiplied by the daily discharge to determine the magnitude of each respective source water on a daily basis. Relative contributions of each of the source waters were reported as the summation of the daily contributions using the median value. Uncertainty was reported as the maximum difference in relative contribution encountered across all combinations of EMMA using median and interquartile values for each end-member.

\section{Results}

\subsection{Climate}

Mean annual air temperature decreased with increasing elevation, from $6.6^{\circ} \mathrm{C}$ at $\mathrm{GG}$ to $-3.4^{\circ} \mathrm{C}$ at $\mathrm{D}-1$, which corresponds to a decrease of $-8.9^{\circ} \mathrm{C}$ per $1000 \mathrm{~m}$ (Table 2). The daily mean air temperature remained below freezing from October to mid-May in GL4 and from November to April in CC. There was no corresponding period of 
continuously freezing air temperatures at GG. Annual precipitation (measured by water year) and the percentage of precipitation as snow generally increased with elevation (Table 2), which is common to mountain regions around the world [Barry, 2008; Körner, 2007; Williams et al., 2011]. Over the three-year study, precipitation increased from an annual average of $532 \mathrm{~mm}$ (40\% snow) at GG to $962 \mathrm{~mm}$ (69\% snow) at CC and 1439 $\mathrm{mm}(83 \%$ snow) at GL4. Therefore, the transition from rain- to snow-dominated precipitation in the Boulder Creek Watershed occurred at an elevation between the GG and CC catchments. The annual amount of snow increased with elevation at a rate of 80 $\mathrm{mm}$ per $100 \mathrm{~m}$ elevation increase in $2010,119 \mathrm{~mm}$ per $100 \mathrm{~m}$ in 2011 , and $52 \mathrm{~mm}$ per $100 \mathrm{~m}$ elevation in 2012. Relative to the previous 30-yr record (1980-2010), total precipitation was above average for all catchments in 2011, while total precipitation was below average (in GL4 and GG) to near average (in CC) in 2012. In particular, the spring (March-May) precipitation and peak SWE were much lower in 2012 compared to the previous two years (Table 2), and the snow depth at maximum accumulation across the GL4 catchment averaged $94 \mathrm{~cm}(\mathrm{n}=495)$, which was less than the previous historical low of $123 \mathrm{~cm}$ in 2002 [Williams et al., 2006]. In 2012, all catchments also experienced the greatest percent contribution of annual precipitation occurring as rain, which was attributed to both low total snowfall and above normal rainfall in July 2012. Mixed precipitation was minimal at GL4 $(2 \% ; \sigma$ (standard deviation $)=1 \%$ annually $)$, and increased to $7 \%(\sigma=4 \%)$ at CC and $21 \%(\sigma=11 \%)$ at GG; the year-to-year variability in annual mixed precipitation decreased with elevation (Table 2). In 2012, mixed precipitation was a much smaller percentage of the total annual precipitation in GG, and also decreased in CC but not in GL4. These mixed precipitation patterns indicate that the 
$1.8^{\circ} \mathrm{C}$ air temperature phase change threshold was infrequently crossed during precipitation events at the highest elevations (GL4) but increased in frequency as elevation decreased (GG and $\mathrm{CC}$ ). Our results also indicate that the occurrence of air temperature fluctuations around the $1.8^{\circ} \mathrm{C}$ threshold more significantly influenced the annual rain/snow ratios in years when larger amounts of precipitation occurred during the spring (March-May).

$<$ Table 2 here please >

\subsection{Surface water and groundwater response to precipitation}

Stream discharge and groundwater recharge (measured as an increase in water table height) were strongly coupled with the timing and magnitude of snowmelt (measured as reduction in SWE) in all catchments (Figure 2). In 2010 and 2011, all catchments produced snowmelt-dominated hydrographs with low baseflow followed by a steep rising limb during snowmelt and a more gradual receding limb returning to baseflow by late summer (Figure $2 \mathrm{~g}$-i). During the snowmelt-dominated years, the annual specific discharge increased with increasing elevation, from $54 \mathrm{~mm}$ at GG to $232 \mathrm{~mm}$ at CC to $1252 \mathrm{~mm}$ at GL4 (Table 2). In contrast, in the rain-dominated year of 2012, the peak snowmelt discharge (i.e. associated with or immediately following the SWE recession limb) was only about $30 \%$ of the magnitude of the other years for all catchments. Although the maximum 2012 SWE in GG was comparable to previous years, the stream did not show a distinct peak in discharge related to snowmelt (Figure $2 \mathrm{~g}$ ), likely related to the considerably lower total spring (March-May) precipitation that year (Table 2). In 2012, the annual discharge peaked in July in all catchments immediately following a large elevation-independent rainfall event that exceeded $100 \mathrm{~mm}$ cumulative 
precipitation; this was the first time in the 30-year history of the Niwot Ridge LTER data records that peak discharge at GL4 did not occur during snowmelt [Williams and Caine, 2001].

Groundwater levels showed a similar response to snowmelt in all catchments with decreases in depth to water corresponding to annual inputs from melting snowpack (Figure 2d-f). Specifically, in 2011, groundwater levels across all catchments rapidly responded to decreases in SWE and this increase occurred concurrently with the rising limbs of the stream hydrographs (Figure 2). In 2012, groundwater levels again responded to snowmelt, but increases in all wells were subdued compared to the previous year. Following the large rain event in July 2012 (indicated by the vertical dashed line in Figure 2), groundwater levels rapidly increased in GG but the corresponding increase was difficult to detect in CC and GL4 due to overlap with recession from snowmelt recharge (Figure 2).

$<$ Figure 2 here please >

\subsection{Stream Water Chemistry}

Temporal variation in stream solute concentrations exhibited a similar pattern with dilution during snowmelt followed by enrichment of most solutes during the hydrograph recession (Figure 3a-c). Total solute concentrations were highest in GG and decreased with elevation with the exception of $\mathrm{SO}_{4}{ }^{2-}$, which was lowest at the middle elevation catchment (CC). Seasonal variation in the ANC was much larger than the other solutes within the GG catchment, and the ANC concentrations were higher at GG than in the higher elevation catchments. At $\mathrm{CC}$, the $\mathrm{ANC}, \mathrm{Ca}^{2+}$, and $\mathrm{Si}$ varied most with season while $\mathrm{Ca}^{2+}$ and $\mathrm{SO}_{4}{ }^{2-}$ were the most seasonally variable at GL4. Interestingly, in 2012, 
after a dry period between March and June, both $\mathrm{Ca}^{2+}$ and $\mathrm{SO}_{4}{ }^{2-}$ increased throughout the summer (July through September) at GL4, but decreased in both CC and GG, perhaps indicating a shift in source water contributions to GL4 over this period.

The stream water isotopes $\left(\delta^{18} \mathrm{O}\right)$ were seasonally depleted during snowmelt then enriched during the hydrograph recession limb (Figure 3d). The seasonal isotopic depletion was comparable at GL4 and CC (maximum $\delta^{18} \mathrm{O}$ depletion was -18.6\%o and 19.0\%, respectively) but GL4 had greater seasonal enrichment and thus the larger mean annual isotopic amplitude (6.5\%o versus 4.2\%, respectively). The GL4 catchment showed the largest and longest enrichment signal in 2012, which further indicates the anomalously greater proportion of rain to snow during that year (Table 1). Paradoxically, the 2012 enrichment signal also corresponded to large increases in $\mathrm{Ca}^{2+}$ and $\mathrm{SO}_{4}{ }^{2-}$, suggesting that the source waters during that time also contained high geochemical solute concentrations not typically observed in precipitation. The GG catchment had the smallest mean annual isotopic variability (amplitude $=3.4 \%$ ) and showed the least response to annual snowmelt. However, the GG catchment showed occasional rapid isotopic enrichment in summer, particularly following the July 2012 rain event.

$<$ Figure 3 here please >

Snowpack $\delta^{18} \mathrm{O}$ values averaged approximately -20\%o near maximum accumulation but were as depleted as $-30 \%$ for individual snowfall events. Rainfall events were generally more enriched (-10\% to $-5 \%$ ) and showed little dependence on elevation. The $\delta^{18} \mathrm{O}$ values of streamflow at all three sites generally ranged from $-15 \%$ o to -17\% for the two snow-dominated years (2010 and 2011) (Figure 4).

\subsection{End-Member Chemistry}


The temporal variability of streamflow tracer concentrations was well bracketed by the concentrations observed in potential end-members, suggesting that mixing of the potential source waters was sufficient to explain stream chemistry in each catchment. Box plots (showing median and quartile values with whiskers corresponding to $5^{\text {th }}$ and $95^{\text {th }}$ percentiles and open circles for outliers) of tracer concentrations in stream water and potential end-members are shown in Figure 4; data from multiple end-members of the same type are pooled by catchment (groundwater, soil water, and talus water) or across catchments (rain, snow, and snowmelt).

The geochemical tracers $\left(\mathrm{Ca}^{2+}, \mathrm{Mg}^{2+}, \mathrm{SO}_{4}{ }^{2-}, \mathrm{Si}, \mathrm{ANC}\right)$ were more dilute than the stream chemistry in unreacted source waters (rain, snow, snowmelt) and similar to or more concentrated than the stream chemistry in source waters with subsurface contact (groundwater, soil water, talus water, rock glacier outflow). In general, the geochemical tracer concentrations in groundwater decreased with elevation, indicating shorter flow paths and contact time with increasing elevation. The exception to this was elevated $\mathrm{Si}$ in the middle elevation $\mathrm{CC}$ catchment, which can be explained by groundwater contact with buried moraine deposits across the catchment (Lewis and Grant, 1979). High $\mathrm{SO}_{4}{ }^{2-}$ concentrations measured in rock glacier and talus waters can be explained by the common occurrence of sulfide minerals in the mountain bedrock, and the high rates of weathering on freshly exposed rock and glacial till surfaces [Williams et al., 2006]. The $\delta^{18} \mathrm{O}$ concentrations in the streams and subsurface sources of all catchments were bracketed between rain (more enriched) and snow/snowmelt (more depleted), with median values of groundwater more similar to snow than rain in all catchments. Soil waters had large spatial and temporal variability of $\delta^{18} \mathrm{O}$. The median $\delta^{18} \mathrm{O}$ values of rock 
glacier and talus waters in GL4 were more enriched than the median value of both snow/snowmelt and the stream indicating that some component of talus waters are sourced from rain.

$<$ Figure 4 here please $>$

\subsection{End-Member Mixing Analysis}

Analysis of residuals versus measured tracer concentrations in 2-D mixing space suggested that $\mathrm{Ca}^{2+}, \mathrm{Mg}^{2+}, \mathrm{ANC}$, and $\delta^{18} \mathrm{O}$ were conservative tracers in all three catchments. Additionally, $\mathrm{SO}_{4}{ }^{2-}$ was conservative in GL4, $\mathrm{Si}$ was conservative in $\mathrm{CC}$, and $\mathrm{Na}^{+}$was conservative in both CC and GG. Residuals of these tracers were not correlated with measured concentrations $\left(\mathrm{R}^{2}<0.15\right)$. The RRMSE for the selected tracers was generally $<2 \%$ for all catchments with the exception of ANC in GG (RRMSE $=5 \%)$. Based on the criteria of Hooper [2003], these tracers were considered conservative and acceptable for parameterizing EMMA.

The stream chemistry of all three catchments was explained by 2-D (three endmember) systems. Therefore, a PCA was performed using the correlation matrix of streamflow data to extract eigenvalues and eigenvectors. The first two PCA components explained $95 \%, 92 \%$, and $94 \%$ of the total variance of the streamflow data at the GL4, CC, and GG catchments, respectively. On the basis of the work by Christophersen and Hooper [1992], three end-members were thus sufficient to explain the majority of variance of the solute and isotopic content of streamflow using EMMA. These PCA results were projected using the first two U-space projections (U1 and U2) of stream chemistry to generate mixing diagrams to screen end-members and determine endmembers that contribute to streamflow (Figure 5). All sampled potential end-members 
were plotted along with stream samples to determine the three most dominant sources of streamflow generation in each catchment (Figures 5a-c). The selected end-members were: (1) snow precipitation, (2) talus water, and (3) groundwater well 3 for GL4; (1) snowmelt lysimeter 29, (2) rain water at Soddie, and (3) the deep groundwater well at C1 (C1SWdeep) for CC; and (1) snow precipitation, (2) rain precipitation, and (3) groundwater well 2 at GG. Figure 5d highlights the variability of snow-derived source waters at GL4. The selected end-members enclosed $100 \%$ of stream samples as shown by the black dashed lines. Colored dashed lines denote the $25^{\text {th }}$ and $75^{\text {th }}$ percentiles of endmember composition through time.

$<$ Figure 5 here please $>$

The selected end-members in all catchments were used to perform a threecomponent hydrologic mixing model and calculate the relative contributions of source waters to streamflow in each catchment (Figure 6). Melt water from snow was the most important contributor to discharge at all three catchments. Annual contributions of snowmelt water increased with elevation from $46 \%$ (coefficient of variation $(\mathrm{CV})=33 \%$ ) at $\mathrm{GG}$ to $58 \%(\mathrm{CV}=21 \%)$ at $\mathrm{CC}$ and $61 \%(\mathrm{CV}=11 \%)$ at GL4 (Table 3). Groundwater was generally the second most important contributor to streamflow, with similar influence in the lower two catchments at $28 \%(\mathrm{CV}=21 \%)$ in $\mathrm{GG}$ and $31 \%(\mathrm{CV}=26 \%)$ at $\mathrm{CC}$ but a lesser contribution $(19 \% ; \mathrm{CV}=26 \%)$ at GL4. EMMA results also showed that groundwater contributions increased during snowmelt in all catchments (Figure 6), which was substantiated by the analysis of hydrometric data whereby increases in snowmelt (measured as a reduction in SWE) occurred in conjunction with increasing 
groundwater table height (Figure 2). The pressure response of the hydrologic system therefore supported our interpretation of the mixing model results.

Interestingly, during the low snow year and dry spring of 2012 (Table 2), the groundwater contribution increased in both GG and CC but decreased in GL4. Specifically, the groundwater contribution to streamflow at GL4 was reduced to $<1 \%$ by mid-summer, at which time the talus contribution was greater than any other period of the study (69\% on 30 September 2012). However, this groundwater decrease at GL4 was somewhat offset by an increased talus water contribution from 14\% in 2010 and 2011 to $34 \%$ in 2012 . Overall, the third contributor to streamflow was rain at GG $(27 \%$ of streamflow; $\mathrm{CV}=33 \%)$ and $\mathrm{CC}(11 \% ; \mathrm{CV}=36 \%)$ and talus water at GL4 $(21 \% ; \mathrm{CV}=$ 57\%). In 2012, the contribution from this third end-member increased in all catchments in conjunction with a decrease in snowmelt water.

$<$ Figure 6 here please >

$<$ Table 3 here please >

\subsection{EMMA Uncertainty analysis and Model Validation}

Temporal uncertainty in relative contributions to streamflow was addressed by recalculating contributions at each time step (based on weekly stream sampling) using all combinations of median and inter-quartile tracer values for the three sets of end-members (see Section 3.7). The annual uncertainty ( \pm ) (or intra-annual variability) was reported as the minimum and maximum relative contributions for each end-member that bracketed the relative contributions presented in section 4.5 . The uncertainty was inherently greater for stream samples that plotted closer to end-members because a small shift in endmember location (i.e. placement at quartile rather than median tracer value location) 
translated into a greater change in that end-members contribution relative to a stream sample that was further away. For example, in GL4 the stream experienced a decrease in groundwater contributions during 2012 that moved the stream samples closer to the other two end-members (talus and snow), translating to greater uncertainty in the contributions from those end-members. Overall, the calculated uncertainty suggested that relative contributions of selected end-members would remain proportionate to each other when accounting for temporal variability. The results also demonstrated that performing EMMA with median tracer values was an effective method for calculating relative source water contributions at this location.

The EMMA solutions were evaluated by reproducing concentrations of all conservative tracers from the EMMA model and comparing them to the measured values following the protocol of Williams et al. [2006]. The information presented in Table 4 provides several different measures of the efficacy of the EMMA results. In general, EMMA accurately reproduced the measured concentrations (a perfect match would have a slope of 1 and an $\mathrm{R}^{2}$ of 1 ). For example, the $\mathrm{R}^{2}$ values for all tracers in all catchments were greater than 0.85 with most slopes approaching unity (Table 4$)$. The difference of the means was less than $20 \%$ for all tracers with the exception of ANC in GG (27.9\%), which had higher predicted than measured values but remained highly correlated $\left(\mathrm{R}^{2}=\right.$ 0.97).

$<$ Table 4 here please >

\section{Discussion}

End Member Mixing Analysis (EMMA) showed that both snow and groundwater were important sources of streamflow in three headwater catchments across an elevation 
and ecosystem type gradient. However, talus water supplanted rain water as the third source of streamflow in the alpine catchment where rain was less common. Distinct source waters generally clustered together in mixing space, and an uncertainty analysis demonstrated that the application of EMMA to these three headwater catchments was robust.

Across the elevation gradient, there was a significant but contrasting shift in source water contributions during the low snow year (2012) whereby groundwater increased at the lower and middle elevation forested catchments but decreased at the higher elevation alpine catchment. The 2012 precipitation distribution was anomalous compared to long-term measurements but exemplifies trends in lower 1 April SWE and increased summer precipitation that may be indicative of future climate in the Rocky Mountains [Clow, 2010]. To investigate the mechanistic underpinnings of this differential response, we considered the differences in hydrogeologic structures and specifically the presence/absence of ice features such as rock glaciers and permafrost. For example, the mixing model results show that the bedrock groundwater contribution to streamflow decreased to $<1 \%$ by early July in GL4. This implies that while water already residing in the catchment (i.e. groundwater and talus) is normally a major contributor to streamflow at GL4 [e.g. Liu et al., 2004], the subsurface reservoir may be limited in size. As a result, the combination of a very low snow year, early snowmelt, and high spring temperatures could have resulted in minimal infiltration to the depths of the bedrock aquifer such that the ability to displace existing stored water in this reservoir may have been exhausted by early July. As indicated by Caine [2010], a warmer climate at the elevation of GL4 may initially increase stream discharge in the autumn due to accelerated loss of stored water in 
the form of permafrost and/or rock glacier ice [Williams et al., 2006] in the upper portions of the catchment [Leopold et al., 2011; 2013a]. Additionally, Barnes et al. [2014] documented a long-term increase in geochemical weathering products at GL4 and suggest that thawing permafrost, as indicated by rock glacier and talus blockfield meltwater, is a likely source of these weathering products.

While the groundwater contribution to annual discharge decreased with low snowfall at GL4, the talus contribution more than doubled from $14 \%$ in previous years to $34 \%$ in 2012. This is best explained by the influence of a very large rain event that could have increased the hydrologic connectivity of talus areas to streamflow in an otherwise dry year. Although the $\delta^{18} \mathrm{O}$ values in GL4 were more enriched during the summer relative to previous years (could indicate a direct contribution from rain), there was also a corresponding increase in $\mathrm{Ca}^{2+}$ and $\mathrm{SO}_{4}{ }^{2-}$ (Figure 3c-d), which instead suggests that rain was able to generate significant hydrologic connectivity between the talus reservoir and stream. This conclusion is supported by the location of the talus water end-member in mixing space (Figure 5c), which illustrates that it is a mixture of rain, snow, and rock glacier sources but represents a unique end-member that contributes directly to streamflow. Additionally, with the rain occurring after an anomalously warm and dry spring, greater amounts of previously frozen waters from within the talus reservoir (i.e. ice lenses and permafrost) may have mixed with the new precipitation, mobilized, and moved to the stream throughout the summer and into the autumn. This would essentially represent the earlier, longer, and more significant contribution of talus waters that Caine [2010] suggested could be contributing to the observed increased late summer baseflow in GL4. 
These results are consistent with recent research showing that groundwater in mountain catchments may be an important contributor to streamflow in headwater catchments. For example, Williams et al. [2009] used stable water isotopes and base cation concentrations in $\mathrm{CC}$ to show that much of the streamflow in the upper basin was new snowmelt that had infiltrated through the soil and ultimately recharged the groundwater. The $\delta^{18} \mathrm{O}$ values presented in Figure 4 show that the $\delta^{18} \mathrm{O}$ values in snow were close to and sometimes even overlapped the $\delta^{18} \mathrm{O}$ values in groundwater, which indicates that melting snow was the primary mechanism of groundwater recharge across the entire elevation gradient. This was further corroborated by the rapid increase in groundwater levels in all wells following snowmelt in 2011, but the far lesser response to snowmelt in the low snow year of 2012, especially in GL4 (Figure 2). Liu et al. [2004] used EMMA to suggest that infiltrating snowmelt caused residing groundwater to be delivered to the stream by way of translatory flow, which is stored in the groundwater reservoir and subsequently released as lateral flow via displacement by new water inputs (Table 1). Our results expand this analysis to infer that this translatory flow may also occur at lower elevation and forested catchments.

Not surprisingly, talus areas and groundwater from fractured bedrock were the most important sources of subsurface contributions at the highest elevations (GL4) where the depth of the fracture system can be hundreds of meters thick [Gleeson and Manning, 2008]. Clow et al. [2003] used a combination of hydrogeomorphologic mapping, seismic refraction measurements, and porosity and permeability estimates in a nearby alpine catchment to show that talus slopes were the primary groundwater reservoir, with a maximum storage capacity that was equal to, or greater than, total annual discharge from 
the basin. As a result, this study joins a growing body of work [see also Barear et al., 2015; Table 1] to suggest that alpine talus reservoirs can store significant amounts of precipitation throughout the winter.

At middle elevations (CC), water stored in moraine deposits may have been the most important source of groundwater. Out of the wells sampled for this catchment, the most representative groundwater end-member was from the deepest well at C-1, which sampled water from 22-28 $\mathrm{m}$ depth in glacial deposits residing on top of local bedrock. We therefore conclude that streamflow at $\mathrm{CC}$ is preferentially receiving groundwater that has resided in the glacial deposits. This is supported by the CC mixing diagram where the C-1 shallow groundwater represents a mixture of the selected end-members (Figure 5b), which could be interpreted as rain and/or snow mixing with deep groundwater that is upwelling following snowmelt recharge at higher elevations. Similarly, soil waters from GL4 and CC were also a mixture of distinct end-members and thus not unique contributors to streamflow (Figures 5b-5c) [Brooks et al., 2009]. Within the mixing space for the lowest elevation GG catchment, the north-facing and meadow groundwater wells plotted closer to the stream samples than the south-facing well, indicating that they were more hydrologically connected to the stream. This agrees with previous work that characterized both greater snowpack and snowmelt on north-facing compared to southfacing slopes at this elevation [Hinckley et al., 2012], which suggests that snowmelt on south-facing slopes may not be adequate to drive translatory flow.

\section{Conclusion}

The three catchments characterized by this study were identified as three endmember systems with contributions from groundwater, rain, and snow in the montane and 
subalpine catchments and from groundwater, talus water, and snow in the alpine catchment. On average, annual streamflow was $19 \%$ groundwater, $61 \%$ snow precipitation, and $21 \%$ talus water in the alpine catchment, $31 \%$ groundwater, $58 \%$ snowmelt water, and $11 \%$ rain water in the subalpine catchment, and $28 \%$ groundwater, $45 \%$ snow precipitation, and $27 \%$ rain water in the montane catchment. During average and above average snowfall years, snow-derived waters were the greatest contributor to streamflow in all catchments. However, in 2012, the contribution of snow-derived waters was reduced, and earlier and lesser peak snow-derived water contributions were observed in all catchments. Interestingly, groundwater contributions were greatest in 2012 for the montane and subalpine catchments but were lowest in the alpine catchment. Conversely, talus water contributions more than doubled in the alpine catchment in 2012, while rain water contributions increased in the lower elevation catchments. As a result, this work suggests that groundwater recharge and the ensuing groundwater contribution to streamflow may be oppositely affected during low snow or warmer (rain/snow ratio increases) years in forested versus tundra areas in the mountains, but that future work on the relative efficacy of groundwater recharge from snowmelt versus rainfall is needed. Furthermore, under current conditions, surface water and groundwater interactions controlling streamflow generation at different elevations may be influenced by non-linear variations in air temperature and precipitation, while subsurface contributions (groundwater and talus water) are mainly influenced by the timing and magnitude of recharge and the storage capabilities of the subsurface.

\section{Acknowledgements}

The research was supported by NSF grants DEB 0423662 and DEB 1027341 to the 
Niwot Ridge LTER. Funding was also provided by the NSF Boulder Creek Critical Zone Observatory (NSF-EAR 0724960) and by U.S. Department of Agriculture grant 201267003-19802. Dr. Fengjing Liu provided useful feedback on an early version of this manuscript and Leanne Lestak helped with Figure 1. We also would like to thank the Editor, Associate Editor, and two anonymous reviewers for greatly improving the quality of the final manuscript.

\section{References}

Adam, J.C., Hamlet, A.F., Lettenmaier, D.P., 2009. Implications of global climate change for snowmelt hydrology in the twenty-first century. Hydrol. Process., 23(7), 962-972. doi: 10.1002/hyp.7201.

Ajami, H., Troch, P.A., Maddock, T., Meixner, T., Eastoe, C., 2011. Quantifying mountain block recharge by means of catchment- scale storage- discharge relationships. Water Resour. Res., 47(4). doi: 10.1029/2010WR009598.

Ali, G.A., Roy, A.G., Turmel, M.C., Courchesne, F., 2010. Source-to-stream connectivity assessment through end-member mixing analysis. J. Hydrol., 392(3), 119-135. doi: 10.1016/j.jhydrol.2010.07.049.

Andermann, C., Longuevergne, L., Bonnet, S., Crave, A., Davy, P., Gloaguen, R., 2012. Impact of transient groundwater storage on the discharge of Himalayan rivers. Nature Geoscience, 5, 127-132. doi: 10.1038/NGEO1356.

Ashfaq, M., Ghosh, S., Kao, S., Bowling, L.C., Mote, P., Touma, D., Rauscher, S.A., Diffenbaugh, N.S., 2013. Near-term acceleration of hydroclimatic change in the western U.S. J. Geophys. Res., 118(19), 10,676-10,693. doi: 10.1002/jgrd.50816.

Baraer, M., McKenzie, J., Mark, B.G., Gordon, R., Bury, J., Condom, T., Gomez, J., Knox, S., Fortner, S.K., 2015. Contribution of groundwater to the outflow from ungauged glacierized catchments: a multi-site study in the tropical Cordillera Blanca, Peru. Hydrol. Process., 29, 2561-2581. doi: 10.1002/hyp.10386.

Barnes, R.T., Williams, M.W., Parman, J.K., Hill, K., Caine, N., 2014. Thawing glacial and permafrost features contribute to nitrogen export from Green Lakes Valley, Colorado Front Range, USA. Biogeochem., 117(2-3), 413-430. doi: 10.1007/s10533-013-9886-5.

Barry, R.G. 2008. Mountain Weather and Climate, 3rd edition, Cambridge University 
Press, Cambridge, 506 pp.

Barthold, F.K., Tyralla, C., Schneider, K., Vache, K.B., Frede, H.G., Breuer, L., 2011. How many tracers do we need for end member mixing analysis (EMMA)? A sensitivity analysis. Water Resour. Res., 47, W08519. doi: 10.1029/2011WR010604.

Bavay, M., Lehning, M., Jonas, T. Lowe, H., 2009. Simulations of future snow cover and discharge in Alpine headwater catchments. Hydrol. Process., 23(1), 95-108. doi: 10.1002/hyp.7195.

Beck, H.E., van Dijk, A.I.J.M., Miralles, D.G., de Jeu, R.A.M., Bruijnzeel, L.A., McVicar, T.R., Schellekens, J., 2013. Global patterns in base flow index and recession based on streamflow observations from 3394 catchments. Water Resour. Res., 49, 78437863. doi: 10.1002/2013WR013918.

Befus, K., 2010. Applied geophysical characterization of the shallow subsurface: Towards quantifying recent landscape evolution and current processes in the Boulder Creek watershed, CO. M.A. Thesis, Department of Geology, University of Colorado, Boulder, CO.

Befus, K., Sheehan, A.F., Leopold, M., Anderson, S.P., Anderson, R.S., 2011. Seismic constraints on critical zone architecture, Boulder Creek Watershed, Front Range, Colorado. Vadose Zone J., 10(3), 915-927, doi: 10.2136/vzj2010.0108.

Berghuijs, W.R., Woods, R.A., Hrachowitz, M., 2014. A precipitation shift from snow towards rain leads to a decrease in streamflow. Nature Clim. Change, 4, 583-586, doi: 10.1038/NCLIMATE2246.

Braddock, W.A., Cole, J.C., 1990. Geologic map of Rocky Mountain National Park and vicinity, Colorado. U.S. Geol. Surv. Misc. Invest. Series Map I-1973.

Bradley, W.C., 1987. Erosion surfaces of the Colorado Front Range: a review. In; Geomorphic Systems of North America: Graf, W.L. (ed.), Boulder, Colorado. Geological Society of America, Centennial Special Volume 2, 215-220.

Brooks, J.R., Barnard, H.R., Coulombe, R., McDonnell, J.J., 2009. Ecohydrologic separation of water between trees and streams in a Mediterranean climate. Nat. Geosci., 3, 100-104. doi: 10.1038/NGEO722.

Caine, N., 2010. Recent Hydrologic change in a Colorado alpine basin: An indicator of permafrost thaw? Ann. Glaciol., 51, 130-134. doi: 10.3189/172756411795932074.

Christophersen N., Hooper, R.P., 1992. Multivariate analysis of stream flow chemical data: the use of principal components analysis for the endmember mixing problem. Water Resour. Res., 28(1), 99-107. doi: 10.1029/91WR02518. 
Christophersen, N., Neal, C., Hooper, R.P., Vogt, R.D., Andersen, S., 1990. Modeling streamwater chemistry as a mixture of soilwater end-members-A step towards secondgeneration acidification models. J. Hydol., 116, 307-320.

Clow, D.W., Schrott, L., Webb, R., Campbell, D.H., Torizzo, A., Dornblaser, M., 2003. Ground water occurrence and contributions to streamflow in an alpine catchment, Colorado Front Range. Ground Water, 41(7), 937-950. doi: 10.1111/j.17456584.2003.tb02436.x.

Clow, D.W., 2010. Changes in the timing of snowmelt and streamflow in Colorado: A response to recent warming. J. Climate, 23(9), 2293-2306. doi: 10.1175/2009JCLI2951.1.

Cras, A., Marc, V., Travi, Y., 2007. Hydrological behavior of sub-Mediterranean alpine headwater streams in a badlands environment. J. Hydrol, 339, 130-144. doi: 10.1016/j.jhydrol.2007.03.004.

Dai, A., 2008. Temperature and pressure dependence of the rain-snow phase transition over land and ocean. Geophys. Res. Lett., 35, L12802. doi: 10.1029/2008GL033295.

Dailey, K., 2016. Streamflow and groundwater response to precipitation variability in a snow-dominated, subalpine headwater catchment, Colorado Rocky Mountains, USA. M.A. Thesis, Department of Geography, University of Colorado, Boulder, CO.

Earman, S., Campbell, A.R., Phillips, F.M., Newman, B.D., 2006. Isotopic exchange between snow and atmospheric water vapor: Estimation of the snowmelt component of groundwater recharge in southwestern United States. J. Geophys. Res., 111, D09302. doi: 10.1029/2005JD006470.

Eilers, K.A., Debenport, S., Anderson, S., Fierer, N., 2012. Digging deeper to find unique microbial communities: The strong effect of depth on the structure of bacterial and archaeal communities in soil. Soil Biol. Biochem., 50, 58-65. doi:

10.1016/j.soilbio.2012.03.011.

Erickson, T.A., Williams, M.W., Winstral, A., 2005. Persistence of topographic controls on the spatial distribution of snow in rugged mountain terrain, Colorado, United States. Water Resour. Res., 41(4), W04014. doi: 10.1029/2003WR002973.

Fang, X., Pomeroy, J.W., Ellis, C.R., MacDonald, M.K., Debeer, C.M., Brown, T., 2013. Multi-variable evaluation of hydrological model predictions for a headwater basin in the Canadian Rocky Mountains. Hydrol. Earth Syst. Sci., 17, 1635-1659. doi: 10.5194/hess17-1635-2013.

Finger, D., Heinrich, G., Gobiet, A., Bauder, A., 2012. Projections of future water resources and their uncertainty in a glacierized catchment in the Swiss Alps and the subsequent effects on hydropower production during the $21^{\text {st }}$ century. Water Resour. Res. 48. doi: 1.1029/2011WR010733. 
Frisbee, M.D., Phillips, F.M., Campbell, A.R., Liu, F.J., Sanchez, S.A., 2011. Streamflow generation in a large, alpine watershed in the Southern Rocky Mountains of Colorado: Is streamflow generation simply the aggregation of hillslope runoff responses? Water Resour. Res., 47(6), W06512. doi: 10.1029/2010WR009391.

Gleeson, T., Manning, A.H., 2008. Regional groundwater flow in mountainous terrain: Three-dimensional simulations of topographic and hydrogeologic controls. Water Resour. Res., 44(10), W10403. doi: 10.1029/2008WR006848.

Gordon, R.P., Lautz, L.K., McKenzie, J.M., Mark, B.G., Chavez, D., Baraer, M., 2015. Sources and pathways of stream generation in tropical proglacial valleys of the Cordillera Blanca, Peru. J. Hydrol., 522, 628-644. doi: 10.1016.j.jhydrol.2015.01.013.

Green, T.R., Taniguchi, M., Kooi, H., Gurdak, J.J., Allen, D.M., Hiscock, K.M., Treidel, H., Aureli, A., 2011. Beneath the surface of global change: Impacts of climate change on groundwater, J. Hydrol., 405(3-4), 532-560. doi: 10.1016/j.jhydrol.2011.05.002.

Hamlet, A.F., Mote, P.W., Clark, M.P., Lettenmaier, D.P., 2005. Effects of temperature and precipitation variability on snowpack trends in the western United States. J. Climate, 18(21), 4545-4561. doi: 10.1175/JCLI3538.1.

Hazen, J.M., Williams, M.W., Stover, B., Wireman, M., 2002. Characterization of acid mine drainage using a combination of hydrometric, chemical and isotopic analyses, Mary Murphy Mine, Colorado. Environ. Geochem. Hlth. 24, 1-22. doi: 10.1023/A:1013956700322.

Hinckley, E.S., Ebel, B.A., Barnes, R.T., Anderson, R.S., Williams, M.W., Anderson, S.P., 2012. Aspect control of water movement on hillslopes near the rain-snow transition of the Colorado Front Range. Hydrol. Process., 28, 74-85. doi:10.1002/hyp.9549.

Hood. J.L., Hayashi, M., 2015. Characterization of snowmelt flux and groundwater storage in an alpine headwater basin, J. Hydrol., 521, 482-497. doi:

10.1016/j.jhydrol.2014.12.041.

Hooper, R.P., 2001. Applying the scientific method to small catchment studies: a review of the Panola Mountain experience. Hydrol. Process., 15(10), 2039-2050. doi: 10.1002/hyp.255.

Hooper, R.P., 2003. Diagnostic tools for mixing models of stream water chemistry. Water Resour. Res., 39(3), 1055. doi: 10.1029/2002WR001528.

Intergovernmental Panel on Climate Change (IPCC), 2013. Climate Change: The Physical Science Basis, Working group 1 Contribution to the Fifth Assessment Report of the Intergovernmental Panel on Climate Change. Cambridge University Press, Cambridge, United Kingdom. 
James, A.L., Roulet, N.T., 2006. Investigating the applicability of end- member mixing analysis (EMMA) across scale: A study of eight small, nested catchments in a temperate forested watershed. Water Resour. Res., 42(8). doi: 10.1029/2005WR004419.

Janke, J.R., 2005. The occurrence of alpine permafrost in the Front Range of Colorado. Geomorph., 67, 375-389. doi: 10.1016/j.geomorph.2004.11.005.

Jeelani, G.H., Shah, R.A., Jacob, N., Deshpande, R.D., 2016. Estimation of snow and glacier melt contribution to Liddar stream in a mountainous catchment, western Himalaya: an isotopic approach. Isotopes Environ. Health Stud., 1-18. doi: 10.1080/10256016.2016.1186671.

Jepsen, S.M., Molotch, N.P., Williams, M.W., Rittger, K. E., Sickman, J.O., 2012. Interannual variability of snowmelt in the Sierra Nevada and Rocky Mountains, United States: Examples from two alpine watersheds. Water Resour. Res., 48(2). doi: 10.1029/20011WR011006.

Jin, L., Siegel, D.I., Lautz, L.K., Lu, Z., 2012. Identifying streamflow sources during spring snowmelt using water chemistry and isotopic composition in semi-arid mountain streams. J. Hydrol., 40, 289-301. doi: 10.1016/j.jhydrol.2012.09.009.

Kittel, T.G.F., Williams, M.W., Chowanski, K., Hartman, M., Ackerman, T., Losleben, M., Blanken, P.D., 2015. Contrasting long-term alpine and subalpine precipitation trends in a mid-latitude North American mountain system, Colorado Front Range, USA. Plant Ecol. Divers., 8(5-6), 607-624. doi: 10.1080/17550874.2016.1143536.

Klos, P.Z., Link, T.E., Abatzoglou, J.T., 2014. Extent of the rain-snow transition zone in the western U.S. under historic and projected climate. Geophys. Res. Lett., 41, 45604568. doi: 10.1002/2014GL060500.

Knowles, J.F., Harpold, A.A., Cowie, R., Zeliff, M. Barnard, H.R., Burns, S.P., Blanken, P.D., Morse, J.F., Williams, M.W., 2015. The relative contributions of alpine and subalpine ecosystems to the water balance of a mountainous, headwater catchment. Hydrol. Process., 29, 4794-4808. doi: 10.1002/hyp.10526.

Knowles, N., Dettinger, M.D., Cayan, D.R., 2006. Trends in snowfall versus rainfall in the Western United States. J. Climate, 19(18): 4545-4559. doi: 10.1175/JCLI3850.1.

Körner, C., 2007. The use of 'altitude' in ecological research. Trends Ecol. Evol., 22(11), 569-574. doi: 10.1016/j.tree.2007.09.006.

Leopold, M., Völkel, J., Dethier, D.P., Williams, M.W., 2013a. Changing mountain permafrost from the 1970s to today - comparing two examples from Niwot Ridge, Colorado Front Range, USA. Z. Geomorphol., Supplementary Issue, 58(1), 137-157. doi: 10.1127/0372-8854/2013/S-00129. 
Leopold, M., Völkel, J., Huber, J., Dethier, D.P., 2013b. Subsurface architecture of the Boulder Creek Critical Zone Observatory from electrical resistivity tomography. Earth Surf. Proc. Land., 38, 1417-1431. doi: 10.1002/esp.3420.

Leopold, M., Völkel. J, Dethier, D.P., Huber, J., Steffens, M., 2011. Characteristics of a paleosol and its implication for the Critical Zone development, Rocky Mountain Front Range of Colorado, USA. Appl. Geochem., 26, 72-75. doi:

10.1016/j.apgeochem.2011.03.034.

Lewis, W.M., Grant, M.C., 1979. Changes in the output of ions from a watershed as a result of the acidification of precipitation, Ecology, 60(6), 1093-1097. doi:

$10.2307 / 1936955$.

Liu, F.J., Williams, M.W., Caine, N., 2004. Source waters and flow paths in an alpine catchment, Colorado Front Range, United States. Water Resour. Res., 40, W09401. doi: 10.1029/2004WR003076.

Liu, F.J., Parmenter, R., Brooks, P.D., Conklin, M.H., Bales, R.C., 2008. Seasonal and interannual variation of streamflow pathways and biogeochemical implications in semiarid, forested catchments in Valles Caldera, New Mexico. Ecohydrol., 1, 239-252. doi: 10.1002/eco.22.

Luce, C.H., Abatzoglou, J.T., Holden, Z.A., 2013. The missing mountain water: Slower westerlies decrease orographic enhancement in the Pacific Northwest USA. Science, 342, 1360-1364. doi: 10.1126/science.1242335.

Manning, A.H., Caine, J.S., 2007. Groundwater noble gas, age, and temperature signatures in an Alpine watershed: Valuable tools in conceptual model development. Water Resour. Res., 43(4), 1-16. doi: 10.1029/2006WR005349.

Marks, D., Winstral, A., Reba, M., Pomeroy, J., Kumar, M., 2013. An evaluation of methods for determining during-storm precipitation phase and the rain/snow transition elevation at the surface in a mountain basin. Adv. Water Resour., 55, 98-110. doi: 10.1016/j.advwatres.2012.11.012.

Maurya, A.S., Shah, M., Deshpande, R.D., Bhardwaj, R.M., Prasad, A., Gupta, S.K., 2011. Hydrol. Process., 25, 1521-1530. doi: 10.1002/hyp.7912.

McVicar, T.R., Van Niel, T.G., Roderick, M.L., Li, L.T., Mo, X.G., Zimmermann, N.E., Schmatz, D.R., 2010. Observational evidence from two mountainous regions that nearsurface wind speeds are declining more rapidly at higher elevations than lower elevations: 1960-2006. Geophys. Res. Lett., 37, L06402, doi: 10.1029/2009GL042255.

Meixner, T., Manning, A.H., Stonestrom, D.A., Allen, D.M., Ajami, H., Blasch, K.W., Brookfield, A.E., Castro, C.L., Clark, J.F., Gochis, D.J., Flints, A.L., Neff, K.L., Niraula, 
R., Rodell, M., Scanlon, B.R., Singha, K., Walvoord, M.A., 2016. Implications of projected climate change for groundwater recharge in the western United States. J. Hydrol., 534, 124-138. doi: 10.1016/j.jhydrol.2015.12.027.

Molotch, N.P., Meixner, T., Williams M.W., 2008. Estimating stream chemistry during the snowmelt pulse using a spatially distributed, coupled snowmelt and hydrochemical modeling approach. Water Resour. Res., 44, W11429. doi: 10.1029/2007WR006587.

Nolin, A.W., Daly, C., 2006. Mapping "At Risk” Snow in the Pacfic Northwest, J. Hydrometeorology, 7, 1164-1171. doi: http://dx.doi.org/10.1175/JHM543.1.

Olyphant, J., Pelletier, J.D., Johnson, R., 2016. Topographic correlations with soil and regolith thickness from shallow-seismic refraction constraints across upland hillslopes in the Valles Caldera, New Mexico, Earth Surf. Proc. Land. doi: 10.1002/esp.3941.

Perrot, D., Molotch, N.P., Musselman, K.T., Pugh, E.T., 2014. Modeling the effects of the mountain pine beetle on snowmelt in a subalpine forest. Ecohydrol., 7(2), 226-241. doi: $10.1002 /$ eco.1329.

Pielke, R.A., 2005. Land use and climate change. Science, 310(5754), 1625-1626. doi: $10.1126 /$ science. 1120529 .

Rasmussen, R., Baker, B., Kochendorfer, J., Meyers, T., Landolt, S., Fischer, A.P., Black, J., Theriault, J.M., Kucera, P., Gochis, D., Smith, C., Nitu, R., Hall, M., Ikeda, K., Gutmann, E., 2012. How well are we measuring snow? The NOAA/FAA/NCAR winter precipitation test bed. Bull. Amer. Meteorol. Soc., 93(6), 811-829. doi: 10.1175/BAMSD-11-00052.1.

Shaw, G.D., Conklin, M.H., Nimz, G.J., Liu, F., 2014. Groundwater and surface water flow to the Merced River, Yosemite Valley, California: ${ }^{36} \mathrm{Cl}$ and $\mathrm{Cl}^{-}$evidence, Water Resour. Res., 50(3), 1943-1959.

Spencer, S., Anderson, A., Silins, U., Bladon, K., Collins, A., 2014. Towards understanding the spatial and temporal characteristics of stream, hillslope, and groundwater runoff processes in a Rocky Mountain headwater catchment in Alberta, Canada, Geophys. Res. Abs., 16, EGU2014-4576.

Stewart, I.T., Cayan, D.R., Dettinger, M.D., 2005. Changes toward earlier streamflow timing across western North America. J. Climate, 18, 1136-1155. doi: 10.1175/JCLI3321.1.

Stewart, I.T., 2009. Changes in snowpack and snowmelt runoff for key mountain regions. Hydrol. Process., 23(1), 78-94. doi: 10.1002/hyp.7128. 
Tague, C., Grant, G.E., 2009. Groundwater dynamics mediate low-flow response to global warming in snow-dominated alpine regions. Water Resour. Res., 45(7), W07421. doi: 10.1029/2008WR007179.

Viviroli, D., Archer, D.R., Buytaert, W., Fowler, H.J., Greenwood, G.B., Hamlet, A.F., Huang, Y., Koboltschnig, G., Litaor, M.I., López-Moreno, J.I., Lorentz, S., Schädler, B., Schreier, H., Schwaiger, K., Vuille, M., Woods, R., 2011. Climate change and mountain water resources: overview and recommendations for research, management and policy. Hydrol. Earth Syst. Sci., 15, 471-504. doi: 10.5194/hess-15-471-2011.

Viviroli D., Durr, H.H., Messerli, B., Meybeck, M., Weingartner, R., 2007. Mountains of the world, water towers for humanity: typology, mapping, and global significance. Water Resour. Res. 43(7): W07447. doi: 10.1029/2006WR005653.

Wilson, A.M., Williams, M.W., Kayastha, R.B., Racoviteanu, A., 2016. Use of a hydrologic mixing model to examine the roles of meltwater, precipitation, and groundwater in Langtang River Basin, Nepal. Ann. Glaciol., 57(71), 155-168. doi: 10.3189/2016AoG71A067.

Williams, M.W., Wilson, A., Tshering, D., Thapa, P., Kayastha, R.B., 2016. Using geochemical and isotopic chemistry to evaluate glacier melt contributions to the Chamkar Chhu (river), Bhutan. Ann. Glaciol., 57(71). doi: 10.3189/2016AoG71A068.

Williams, M.W., Barnes, R.T., Parman, J. N., Freppaz, M., Hood, E., 2011. Stream water chemistry along an elevational gradient from the Continental Divide to the foothills of the Rocky Mountains. Vadose Zone J., 10(3), 900-914. doi: 10.2136/vzj2010.0131.

Williams, M.W., Seibold, C., Chowanski, K., 2009. Storage and release of solutes from a sub-alpine seasonal snowpack: soil and stream water response, Niwot Ridge, Colorado. Biogeochem., 95, 77-94. doi: 10.1007/s10533-009-9288-x.

Williams, M.W., Knauf, M., Caine, N., Liu, F., Verplanck, P.L., 2006. Geochemistry and source waters of rock glacier outflow, Colorado Front Range. Permafrost Periglac., 17, 13-33. doi: 10.1002/ppp.535.

Williams, M.W., Caine, N., 2001. Hydrology and hydrochemistry. Structure and function of an alpine ecosystem: Niwot Ridge. Oxford University Press, New York, 75-96.

Williams, M.W., Cline, D., Hartmann M., Bardsley, T., 1999. Data for snowmelt model development, calibration, and verification at an alpine site, Colorado Front Range. Water Resour. Res., 35(10), 3205-3209. doi: 10.1029/1999WR900088.

Williams, M.W., Bardsley, T., Rikkers, M., 1998. Oversampling of snow and overestimation of inorganic nitrogen wetfall using NADP data, Niwot Ridge, Colorado. Atmos. Environ., 32(22), 3827-3833. doi: 10.1016/S1352-2310(98)00009-0. 
Williams, M.W., Losleben, M., Caine, N., Greenland, D., 1996. Changes in climate and hydrochemical responses in a high-elevation catchment in the Rocky Mountains, USA. Limnol. Oceanogr., 41, 939-946.

Williams, M.W., Melack, J.M., 1991a. Precipitation chemistry in and ionic loading to an alpine basin, Sierra Nevada. Water Resour. Res., 27(7), 1563-1574.

Williams, M.W., Melack, J.M., 1991b. Solute chemistry of snowmelt and runoff in an alpine basin, Sierra Nevada. Water Resour. Res., 27(7), 1575-1588. 


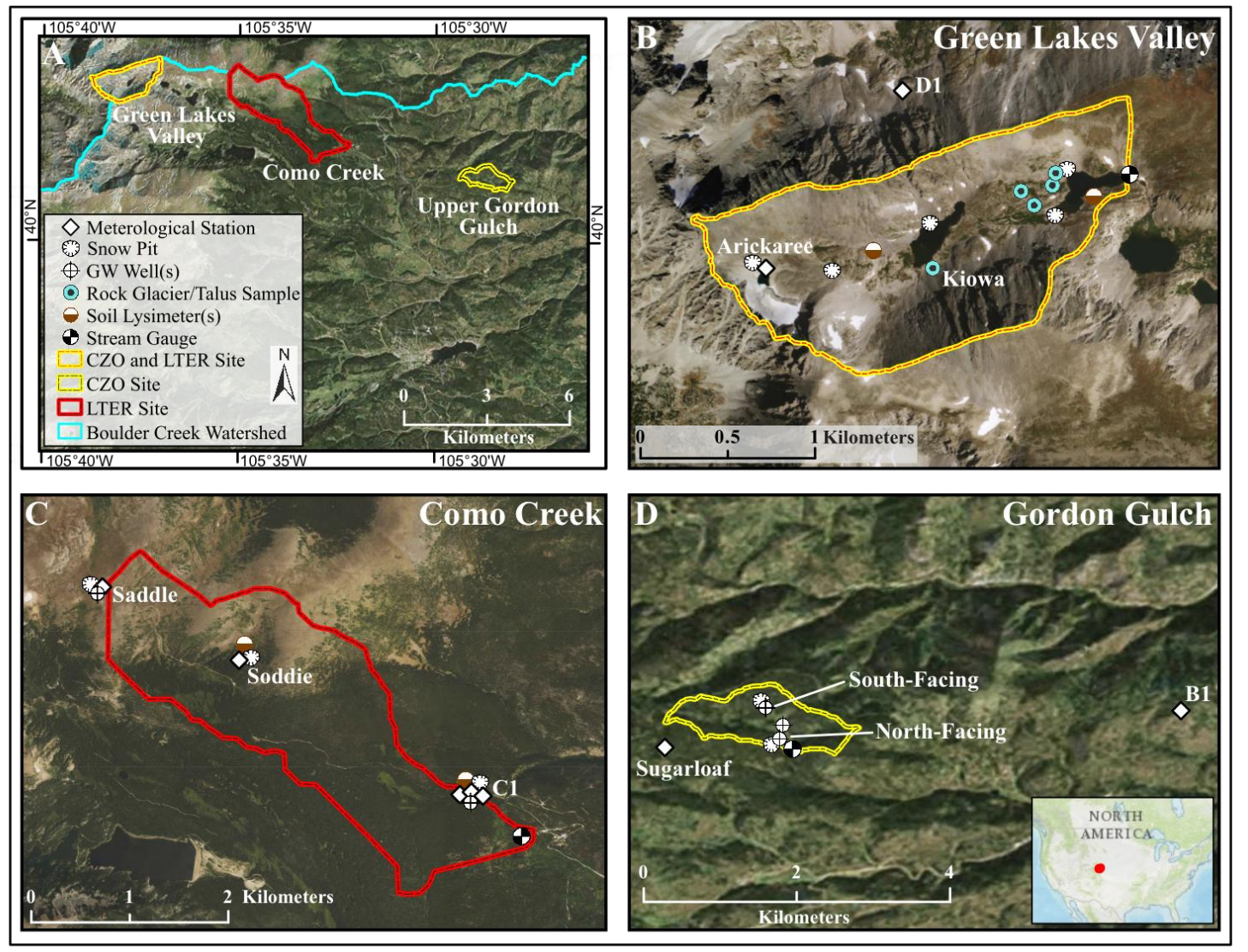

Figure 1: (a) Boulder Creek watershed showing locations of each of the three headwater catchments: (b) Green Lake 4 (GL4), (c) Como Creek (CC), and (d) Gordon Gulch (GG). The relative location of the Boulder Creek watershed in the Rocky Mountains, USA is provided in the panel (d) inset for reference. Locations of all meteorological stations, stream gauges, and source water sampling points are shown. Imagery for backdrop provided by ArcGIS, USDA FSA NAIP 2015. 

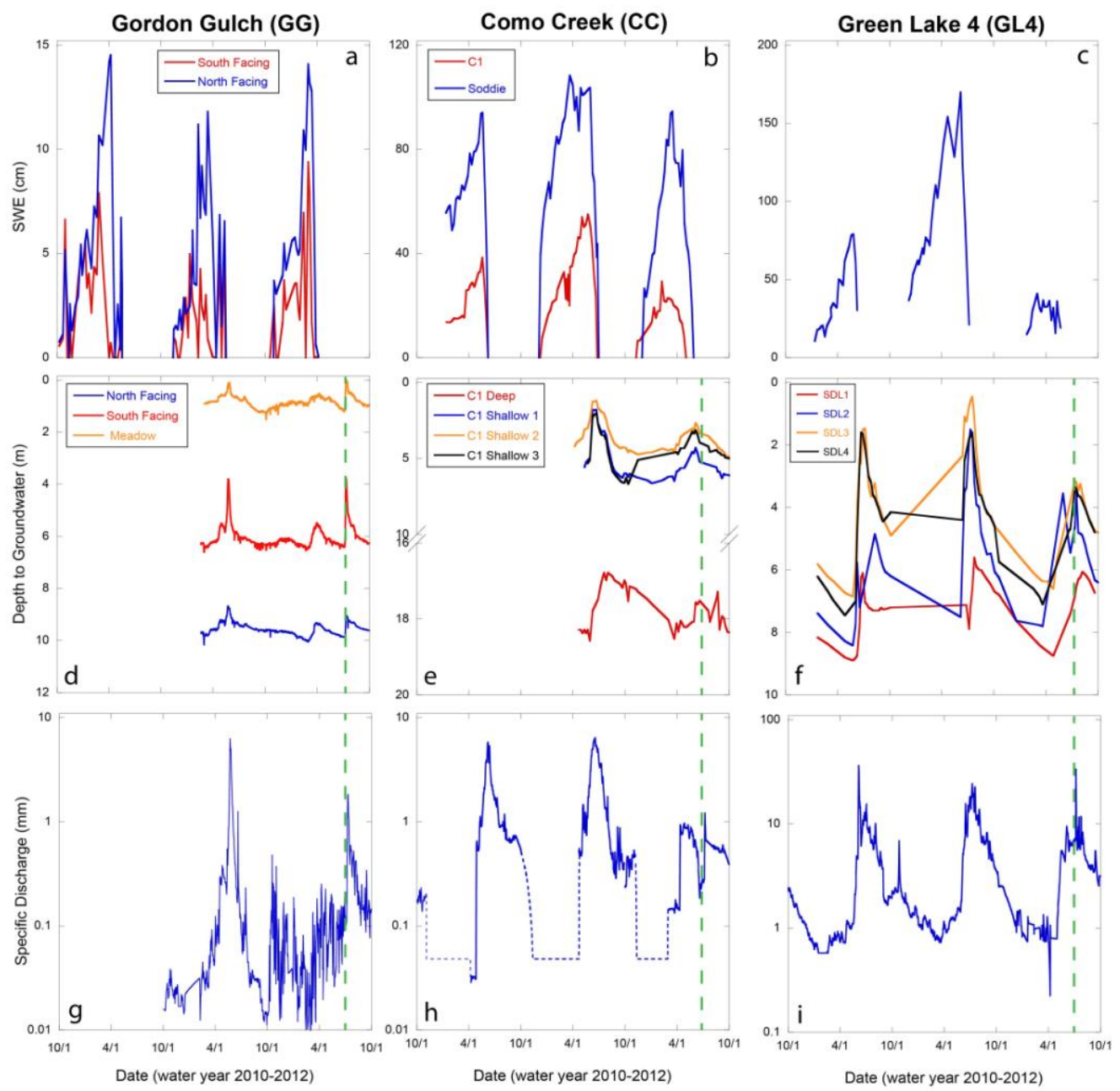

Figure 2: Stacked time series' of snow water equivalent (SWE), depth to groundwater, and specific discharge for water years 2010 to 2012. The vertical columns represent each catchment. Top row panels (a-c) are measured SWE for (a) north and south facing slopes in GG, (b) C-1 and Soddie sites in CC, and (c) the Saddle site near GL4. Middle row (d-f) shows the depth to groundwater from all sampled wells: (d) GG, (e) CC), and (f) GL4. Bottom row (g-i) is specific discharge for: (g) GG, (h) CC, and (i) GL4. The discharge was plotted on a log scale to highlight variability during low flows and estimated winter values for $\mathrm{CC}$ are denoted with dashed lines. The vertical dashed green lines in panels $\mathrm{d}-\mathrm{i}$ mark an exceptional rain event during 5-9 July, 2012, which produced > $100 \mathrm{~mm}$ of precipitation in all catchments. 

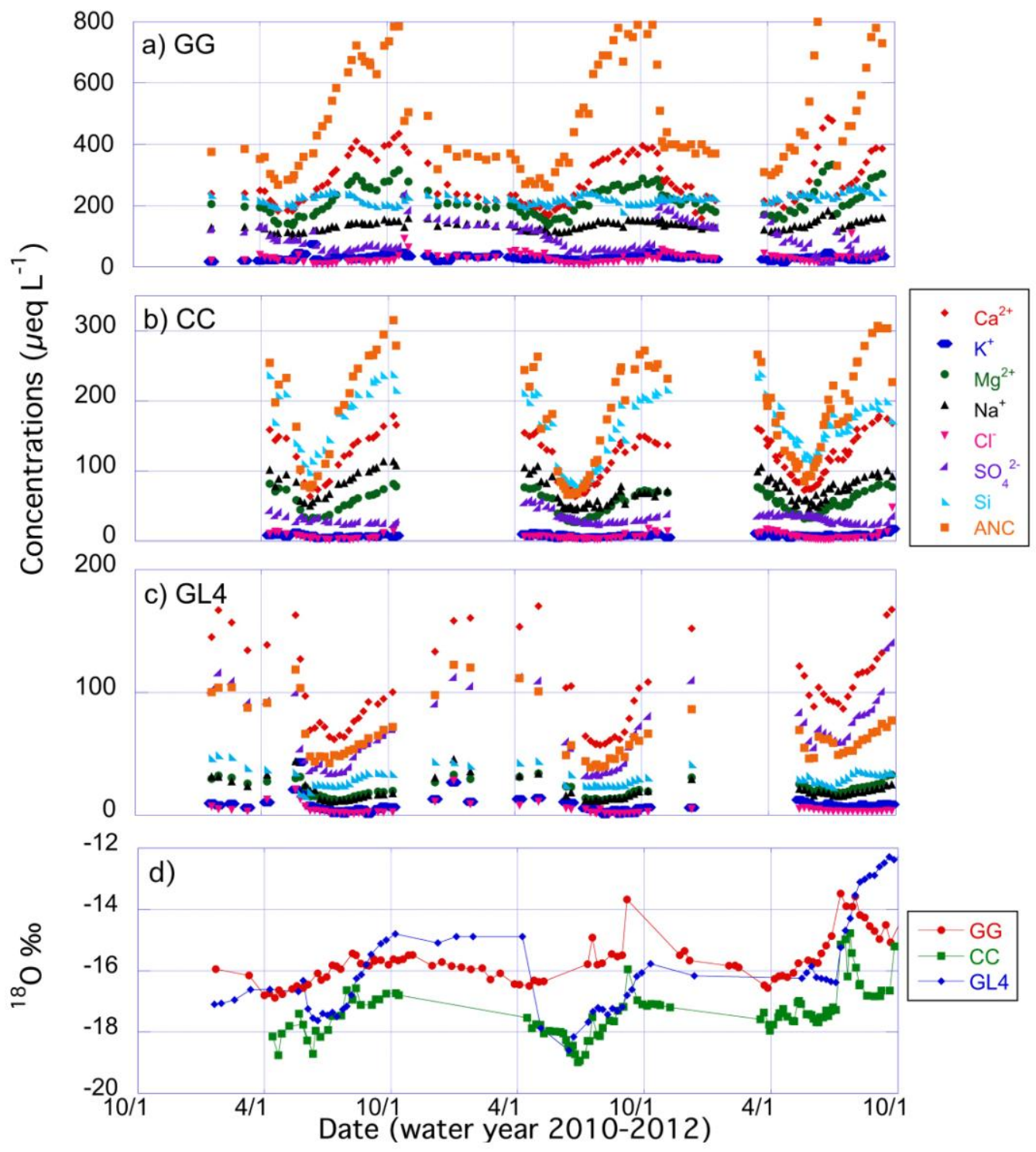

Figure 3: Time series of (a-c) solute and (d) $\delta^{18} \mathrm{O}$ concentrations in stream chemistry. Stream samples were collected approximately weekly throughout the study period with some longer periods between samples during winter months when access was limited in GL4 and CC. ANC is acid neutralizing capacity. 

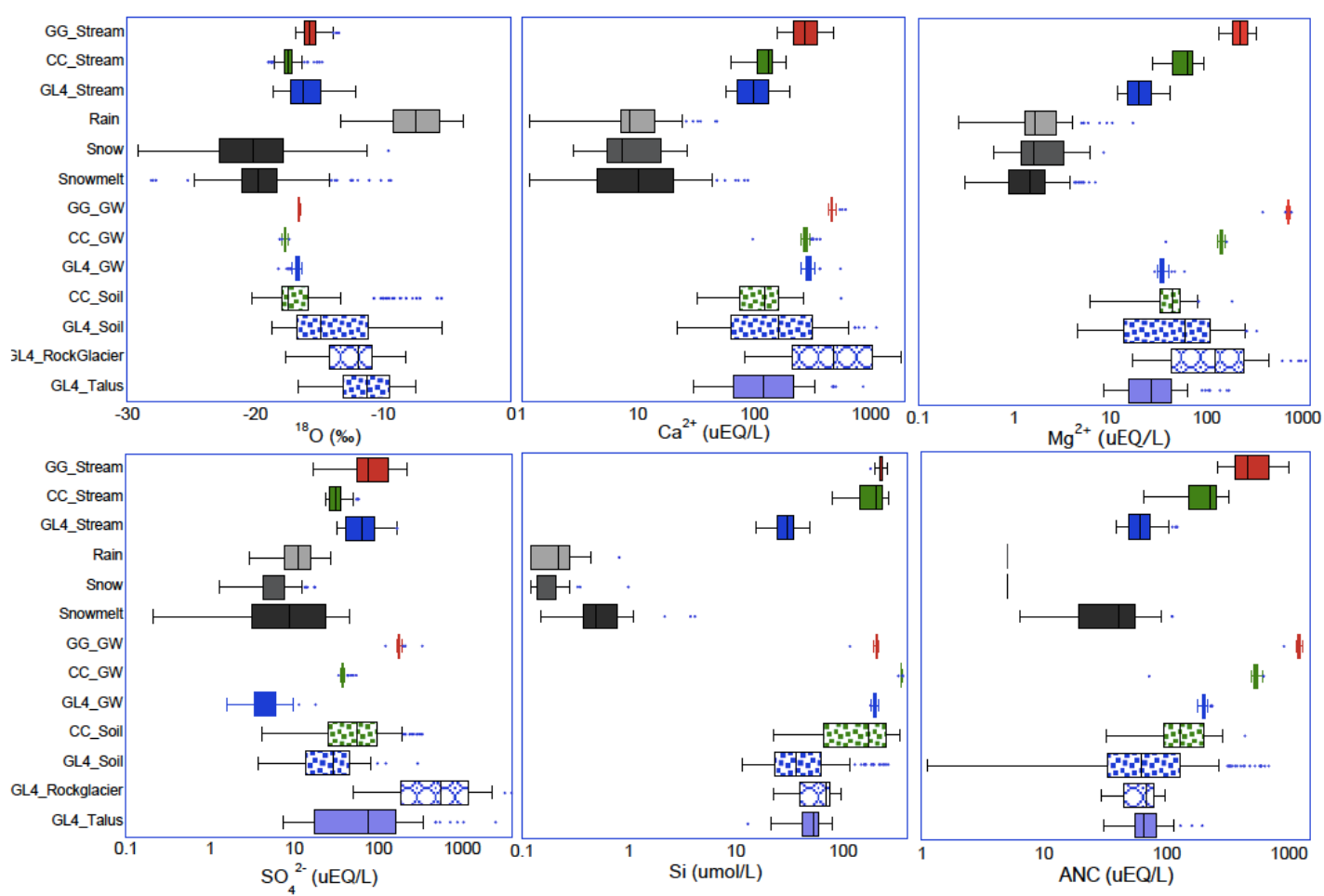

Figure 4: Box-and-whisker plots for $\mathrm{Ca}^{2+}, \mathrm{Mg}^{2+}, \mathrm{SO}_{4}{ }^{2-}, \mathrm{Si}, \mathrm{ANC}$, and $\delta^{18} \mathrm{O}$ values in stream waters and potential end-members. The potential end-member color matches the corresponding stream plots with red for GG, green for CC, and blue for GL4. Rain and snow values were combined from all sample locations. Median values are shown since EMMA uses median values to parameterize end-members in the PCA. 

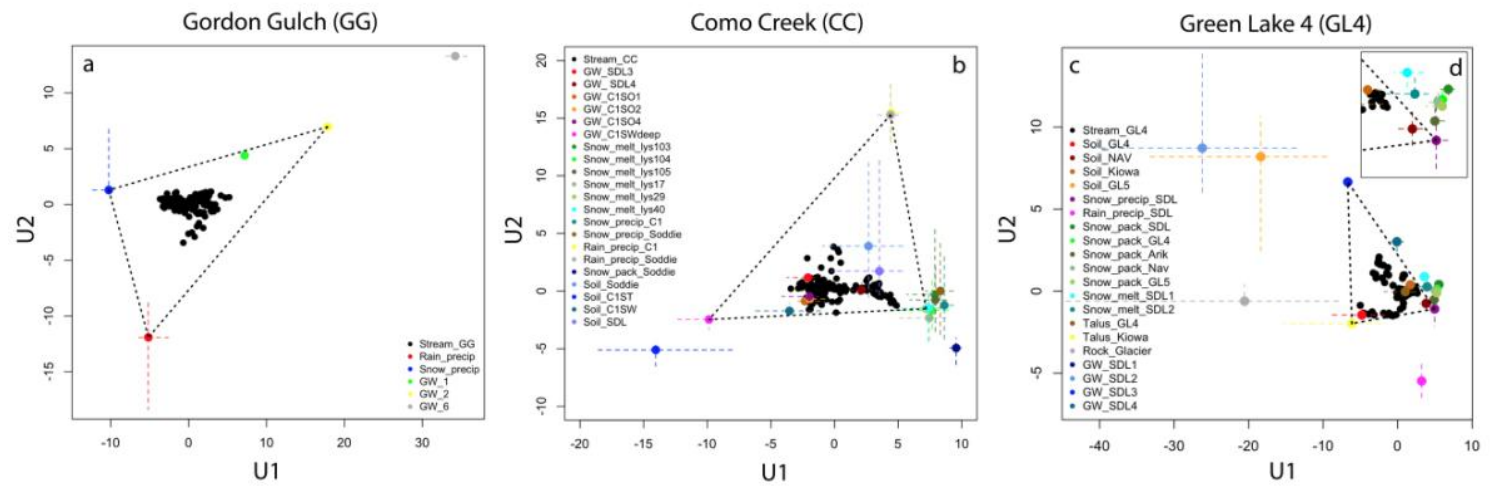

Figure 5: Mixing diagrams (in U space) for (a) GG, (b) CC, and (c) GL4 including all stream samples (black dots) and potential end-members (colored dots) except for Groundwater Well 1 at GL4 that plotted at U1,147; U2,64. Potential end-members were projected using median values of selected tracers with colored dashed lines corresponding to the interquartile range $(25 \%-75 \%)$ of variability and selected endmembers are connected with black dashed lines. (d) is a zoom of the snow end-member cluster at GL4. 


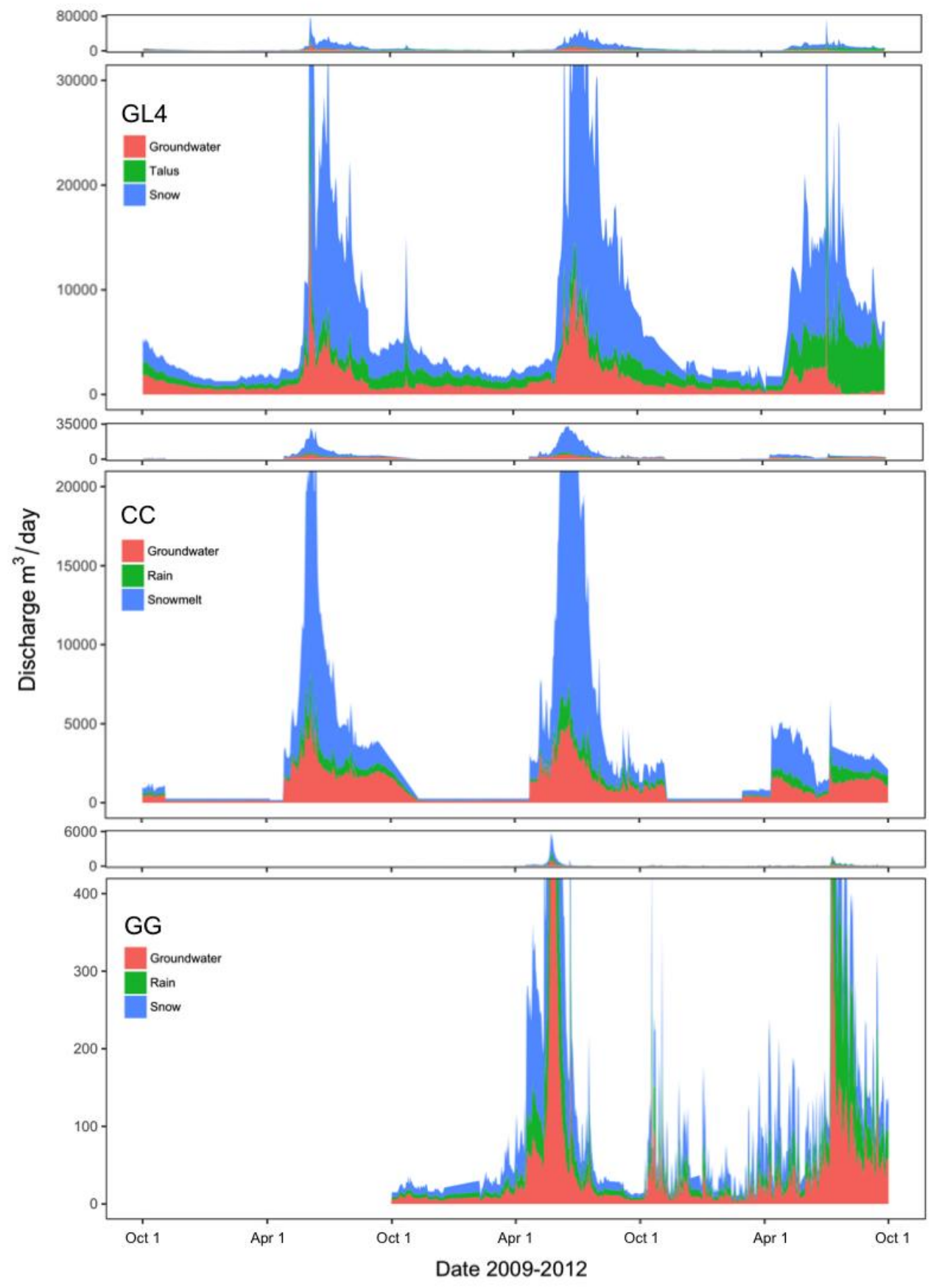

Figure 6: Hydrograph separation for GL4 (2010-2012), CC (2010-2012), and GG (20112012). Daily discharge was measured and daily source-water contributions were linearly interpolated based on the observed samples. See Figure $2 \mathrm{~h}$ for the time periods during which the CC flow record was estimated. Insets above each panel are included to highlight the full range of hydrograph variability within each catchment. 
Table 1: Tabular literature review of research relevant to the study of mountain catchment source waters using isotopes, geochemistry, and hydrologic mixing models. Abbreviations used in the table correspond to groundwater (GW), snowmelt (SM), surface water (SW), End-Member Mixing Analysis (EMMA), electrical conductivity (EC), alkalinity (ALK), and unknown (unkn).

\begin{tabular}{|c|c|c|c|c|}
\hline Paper & $\begin{array}{c}\text { Location; } \\
\text { Annual } \\
\text { Precipitation } \\
\text { (Percent Snow) }\end{array}$ & $\begin{array}{c}\text { Approach; Data } \\
\text { Used; Sources } \\
\text { (Number of Samples } \\
\text { if Known) }\end{array}$ & $\begin{array}{c}\text { Catchment Type } \\
\text { (Number); Size(s); } \\
\text { Elevation; Length of } \\
\text { Study; Sampling } \\
\text { Frequency or Number } \\
\text { of Sampling Events; } \\
\text { Instrumentation } \\
\end{array}$ & Key Results \\
\hline $\begin{array}{c}\text { Liu et al., } \\
2004\end{array}$ & $\begin{array}{l}\text { Colorado Rocky } \\
\text { Mountains, USA; } \\
\begin{array}{c}100+\mathrm{cm}(80 \% \\
\text { snow) }\end{array}\end{array}$ & $\begin{array}{c}\text { EMMA; } \\
\delta^{180} \text { and geochemical } \\
\text { tracers; Rain, snow, } \\
\text { snowmelt, soil water, } \\
\text { talus water, fall } \\
\text { stream baseflow (no } \\
\text { groundwater) }\end{array}$ & $\begin{array}{l}\text { Glacial alpine headwater } \\
\text { (2); } 2.25 \mathrm{~km}^{2} ; 3250-4000 \\
\text { m asl; > } 1 \text { year; Gauged }\end{array}$ & $\begin{array}{l}\text { Sources: GW }>60 \% \text { of discharge } \\
\text { even during melt season, } \mathrm{SM} \text {, talus } \\
(>40 \% \text { in summer), baseflow } \\
\text { (assumed from fractured bedrock) }\end{array}$ \\
\hline $\begin{array}{l}\text { James and } \\
\text { Roulet, } 2006\end{array}$ & $\begin{array}{l}\text { Quebec, Canada; } \\
94 \mathrm{~cm}(22 \% \\
\text { snow })\end{array}$ & $\begin{array}{l}\text { EMMA; Major ions, } \\
\text { EC, ALK; rain (12), } \\
\text { throughfall (216), } \\
\text { groundwater from } \\
\text { shallow wells, } \\
\text { soil water } \\
\end{array}$ & $\begin{array}{l}\text { Temperate forest, nested } \\
\text { catchments (8); } 1.47 \mathrm{~km}^{2} \text {; } \\
\text { <350 m asl; } 2 \text { years, } 12 \\
\text { storm events; Gauged }\end{array}$ & $\begin{array}{l}\text { Sources: GW, soil water, } \\
\text { throughfall; Conservative tracers } \\
\text { do not mix in the same ratios } \\
\text { across catchments due to soil and } \\
\text { bedrock minerology changes }\end{array}$ \\
\hline $\begin{array}{c}\text { Cras et al., } \\
2007\end{array}$ & $\begin{array}{l}\text { Badlands area of } \\
\text { Southern Alps, } \\
\text { France; } 90 \mathrm{~cm} \\
\text { (0\% snow, flash } \\
\text { flood dominant) }\end{array}$ & $\begin{array}{l}\text { Two-component } \\
\text { mixing, EMMA; } \delta^{18} \mathrm{O} \\
\text { and } \delta \mathrm{D} \text {, and major } \\
\text { ions; rain, soil water, } \\
\text { surface runoff }\end{array}$ & $\begin{array}{c}\text { Sub-Mediterranean } \\
\text { forested headwater } \\
\text { streams (3); } 0.86 \mathrm{~km}^{2} ; \\
847-1259 \text { m asl; } 1 \text { year, } \\
\text { weekly; Gauged }\end{array}$ & $\begin{array}{c}\text { Sources: Shallow GW, deep GW } \\
\text { (only to pre-event water in largest } \\
\text { basin), overland flow (60\%); } \\
\text { Hierarchy of runoff generation } \\
\text { processes not proportional to } \\
\text { basin area; Flash flood } \\
\text { mechanisms identified }\end{array}$ \\
\hline $\begin{array}{l}\text { Liu et al., } \\
2008\end{array}$ & $\begin{array}{l}\text { Sierra Nevada, } \\
\text { CA, USA; } 48 \mathrm{~cm} \\
(40 \% \text { snow })\end{array}$ & $\begin{array}{c}\text { EMMA; diagnostic } \\
\text { tools; snow (1), } \\
\text { subsurface flow (5), } \\
\text { thermal meteoric } \\
\text { waters (8), deep } \\
\text { geothermal water } \\
\text { (11) }\end{array}$ & $\begin{array}{c}\text { Forested (2); 2300-3432 } \\
\text { m asl; < } 1 \text { yr. (23); } \\
\text { Gauged }\end{array}$ & $\begin{array}{c}\text { Sources: Lateral GW flow }(\sim 80 \%) \\
\text { and thermal meteoric water; SM } \\
\text { not a significant source }\end{array}$ \\
\hline $\begin{array}{c}\text { Frisbee et } \\
\text { al., } 2011\end{array}$ & $\begin{array}{c}\text { Rocky } \\
\text { Mountains, CO, } \\
\text { USA; } 21.2 \mathrm{~cm} \\
(70 \% \text { snow } \\
\text { below } 2700 \mathrm{~m} \\
\text { and } 90 \% \text { snow } \\
\text { above } 2700 \mathrm{~m})\end{array}$ & $\begin{array}{c}\text { EMMA, stream } \\
\text { hydraulic head } \\
\text { gradients; } \delta^{18} 0 \text { and } \\
\delta D, \text { and major ions; } \\
\text { rain, snow, soil water, } \\
\text { springs (17), wells } \\
(6), \text { stream } \\
\text { piezometers }(11)\end{array}$ & $\begin{array}{c}\text { Alpine headwater } \\
\text { catchments, nested; } \\
16,000 \mathrm{~km}^{2} ; 2352-4237 \\
\text { m asl; } 4 \text { yrs.; Gauged }\end{array}$ & $\begin{array}{l}\text { GW contributions important at all } \\
\text { scales, and increase with size of } \\
\text { watershed; Surface runoff during } \\
\text { melt season but not from rain }\end{array}$ \\
\hline $\begin{array}{c}\text { Jin et al., } \\
2012\end{array}$ & $\begin{array}{c}\text { Rocky } \\
\text { Mountains, Wind } \\
\text { River Range, WY, } \\
\text { USA; } 55 \mathrm{~cm}(80 \% \\
\text { snow) }\end{array}$ & $\begin{array}{l}\text { 2-EM mixing models; } \\
\delta^{18} 0 \text { and } \delta D \text {, and } \\
\text { major ions; } \\
\text { Snow, groundwater } \\
(32)\end{array}$ & $\begin{array}{c}\text { Forested mountain } \\
\text { catchments (2); } 81 \mathrm{~km}^{2} ; \\
\text { 1708-2767 m asl; } 18 \\
\text { months, weekly; Gauged }\end{array}$ & $\begin{array}{c}\text { Nearly all stream water during } \\
\text { snowmelt derived from GW; } \\
\text { Combining isotope and } \\
\text { geochemical tracers enables } \\
\text { differentiation of GW and SM } \\
\text { sources }\end{array}$ \\
\hline $\begin{array}{c}\text { Maurya et } \\
\text { al., } 2011\end{array}$ & $\begin{array}{l}\text { River Ganga, } \\
\text { Himalayan } \\
\text { region, India; } \\
\text { Unkn. }\end{array}$ & $\begin{array}{c}\text { Three-component } \\
\text { mixing model; }{ }^{18} \mathrm{O} \text { and } \\
\text { EC; Rain, } \\
\text { groundwater, glacial } \\
\text { ice-melt (end- } \\
\text { member values } \\
\text { estimated from } \\
\text { previous work i.e. no } \\
\text { time series } \\
\text { concurrent w/ river }\end{array}$ & $\begin{array}{l}\text { Glacial alpine to forested } \\
\text { foothills; } 19,600 \mathrm{~km}^{2} ; \\
\text { 1,220-5649 m asl; } 16 \\
\text { months }\end{array}$ & $\begin{array}{l}\text { GW } 15 \pm 5 \% \text { of discharge annually; } \\
\text { Surface runoff from SM peaks (70- } \\
90 \%) \text { in winter; Glacier ice melt } \\
32 \%(40 \% \max )\end{array}$ \\
\hline
\end{tabular}




\begin{tabular}{|c|c|c|c|c|}
\hline $\begin{array}{c}\text { Shaw et al., } \\
2014\end{array}$ & $\begin{array}{l}\text { Merced River, } \\
\text { Sierra Nevada, } \\
\text { CA, USA; } \\
91 \mathrm{~cm} \text { (snow/ } \\
\text { rain mix) }\end{array}$ & $\begin{array}{c}\text { 2-tracer 3-component } \\
\text { mixing model; }{ }^{36} \mathrm{Cl}, \mathrm{Cl} \text {, } \\
{ }^{222} \mathrm{Rn}, \delta^{18} \mathrm{O}, \delta \mathrm{D} ; \\
\text { Groundwater wells } \\
\text { (4), springs (5), snow } \\
\text { (3) }\end{array}$ & $\begin{array}{l}20 \mathrm{~km} \text { forested river (not } \\
\text { headwaters); } \sim 3,000 \\
\mathrm{~km}^{2} ; 880-1224 \mathrm{~m} \text { asl; } 3 \\
\text { years (91 samples total } \\
\text { from all sources); Gauged }\end{array}$ & $\begin{array}{l}\text { Sources: Shallow GW, deep GW, } \\
\text { near-surface runoff from recent } \\
\text { meltwater; Snow not an important } \\
\text { contributor }\end{array}$ \\
\hline $\begin{array}{l}\text { Baraer et al., } \\
\quad 2015\end{array}$ & $\begin{array}{c}\text { Cordillera } \\
\text { Blanca, Peru; } \\
\text { Unkn. ( } 80 \% \\
\text { occurs from Oct- } \\
\text { Apr) }\end{array}$ & $\begin{array}{l}\text { Hierarchical cluster } \\
\text { analysis, ANOVA, } \\
\text { mixing diagrams; } \\
\delta^{18} 0, \delta \mathrm{D} \text {, and major } \\
\text { ions; } 2 \text { synoptic } \\
\text { events; Surface water, } \\
\text { glacier melt, } \\
\text { groundwater } \\
\text { (shallow wells), } \\
\text { springs, tributaries }\end{array}$ & $\begin{array}{l}\text { Glacial alpine (3); } 250 \\
\mathrm{~km}^{2} ; 3838 \mathrm{~m} \text { asl (outlet); } \\
\text { 2 years; Ungauged }\end{array}$ & $\begin{array}{l}\text { GW is } 24-80 \% \text { of discharge and } \\
\text { dominant source of discharge in } \\
\text { the dry season; Talus reservoir } \\
\text { stores considerable upslope } \\
\text { precipitation, releases throughout } \\
\text { dry season; Melt water-fed GW } \\
\text { likely more vulnerable to climate } \\
\text { change/cryosphere loss }\end{array}$ \\
\hline $\begin{array}{l}\text { Gordon et } \\
\text { al., } 2015\end{array}$ & $\begin{array}{c}\text { Cordillera } \\
\text { Blanca, Peru; 80- } \\
120 \mathrm{~cm} \text { (unkn.) }\end{array}$ & $\begin{array}{c}\text { Applied tracer, PCA; } \\
\delta^{18} \mathrm{O}, \delta \mathrm{D} \text {, and major } \\
\text { ions, Rhodamine WT } \\
\text { (dye tracer); } \\
\text { Glacial lake (1), } \\
\text { springs, groundwater } \\
\text { wells (18), channel }\end{array}$ & $\begin{array}{c}\text { Meadow/proglacial } \\
\text { stream complexes (2) in } \\
\text { alpine glacierized valleys; } \\
4370 \mathrm{~m} \text { asl; } 0.5 \mathrm{~km}^{2} ;<1 \\
\text { yr (1 synoptic sampling } \\
\text { event) }\end{array}$ & $\begin{array}{l}\text { GW is } \sim 50 \% \text { of discharge and } \\
\text { increases downstream; Moraines } \\
\text { important to GW storage but } \\
\text { recharged by SW; Geomorphology } \\
\text { important control on subsurface } \\
\text { contributions in dry seasons; } \\
\text { Subsurface flow of surface } \\
\text { meltwater acquires geochemical } \\
\text { signature from silicate weathering }\end{array}$ \\
\hline $\begin{array}{l}\text { Wilson et al., } \\
2016\end{array}$ & $\begin{array}{l}\text { Himalaya, } \\
\text { Langtang River, } \\
\text { Nepal; } 62 \mathrm{~cm} \\
\text { (unkn. monsoon } \\
\text { dominant) }\end{array}$ & $\begin{array}{l}\text { EMMA; } \delta^{18} 0 \text { and } \\
\text { geochemical tracers; } \\
\text { Springs (4), glacial } \\
\text { meltwater (72), } \\
\text { glacial ice (2), rain } \\
(1), \text { snow (2) }\end{array}$ & $\begin{array}{c}\text { Glacial alpine-to-forest } \\
\text { transect; } 585 \mathrm{~km}^{2} ; 1460- \\
7246 \text { m asl; } 4 \text { synoptic } \\
\text { events; }\end{array}$ & $\begin{array}{l}\text { GW and glacial melt water } \\
\text { important all year except during } \\
\text { monsoon; Precipitation }<33 \% \text { of } \\
\text { discharge }\end{array}$ \\
\hline $\begin{array}{l}\text { Williams et } \\
\text { al., } 2016\end{array}$ & $\begin{array}{l}\text { Himalaya, } \\
\text { Chamkar Chhu } \\
\text { River, Bhutan; } \\
\text { Unkn. }\end{array}$ & $\begin{array}{l}\text { Two-component } \\
\text { mixing, EMMA; } \delta^{18} 0 \\
\text { and geochemical } \\
\text { tracers; Glacier } \\
\text { outflow (1), springs } \\
\text { (2), ice (2), snow (1) } \\
\text { (rain not measured) } \\
\end{array}$ & $\begin{array}{c}\text { Glacial alpine; } \sim 1800 \\
\mathrm{~km}^{2} ; 2600->6000 \mathrm{~m} \text { asl; } 3 \\
\text { synoptic events }(\mathrm{n}=32) ; 1 \\
\text { year }\end{array}$ & $\begin{array}{l}\text { Sources: GW and glacial melt (31- } \\
76 \% \text { increasing with elevation); } \\
\text { Four-component system: snow (or } \\
\text { ice), shallow GW, deep GW; GW } \\
60-80 \% \text { of discharge at lowest } \\
\text { elevation in July and decreases } \\
\text { with elevation } \\
\end{array}$ \\
\hline $\begin{array}{l}\text { Jeelani et al., } \\
2016\end{array}$ & $\begin{array}{l}\text { Western } \\
\text { Himalaya, Liddar } \\
\text { river in Jammu } \\
\text { and Kashmir; } \\
124 \mathrm{~cm} \text { (winter } \\
\text { snow, summer } \\
\text { rain) } \\
\end{array}$ & $\begin{array}{c}\text { Two-component } \\
\text { mixing, EMMA; } \delta^{18} 0 \text {, } \\
\delta \text { D, EC; Precipitation } \\
(110), \text { snowmelt (18), } \\
\text { glacier melt (80), } \\
\text { groundwater (4 } \\
\text { different springs, 40) } \\
\end{array}$ & $\begin{array}{c}\text { Glacial alpine-to-forest } \\
\text { transect; } 1243 \mathrm{~km}^{2} ; \\
\text { 1600-5200 m asl; } 2 \text { years, } \\
\text { weekly }\end{array}$ & $\begin{array}{l}\text { Sources: Snowmelt (5-66\% } \\
\text { throughout the year), rain }(17 \%) \text {, } \\
\text { glacier melt (5\%, 19\% September } \\
\text { in low snow years); Successful } \\
\text { application of isotope-based } \\
\text { hydrographic separation in snow- } \\
\text { dominated, glaciated catchment }\end{array}$ \\
\hline $\begin{array}{l}\text { Cowie et al. } \\
2016 \text { (this } \\
\text { study) }\end{array}$ & $\begin{array}{c}\text { Rocky } \\
\text { Mountains, } \\
\text { Colorado, USA; } \\
50-150 \text { cm (30- } \\
90 \% \text { snow })\end{array}$ & $\begin{array}{l}\text { EMMA; diagnostic } \\
\text { tools; } \delta^{18} 0 \text {, major } \\
\text { ions; groundwater } \\
(880), \text { soil }(187), \text { rain } \\
\text { (105), snow(221), } \\
\text { snowpack (243), } \\
\text { snowmelt (268), rock } \\
\text { glacier outflow (60), } \\
\text { talus water (70) } \\
\end{array}$ & $\begin{array}{l}\text { Forested and alpine } \\
\text { headwater catchments } \\
\text { along an elevational } \\
\text { gradient (3); } \\
3 \text { years, weekly }\end{array}$ & $\begin{array}{l}\text { Sources: GW, snow, rain, talus } \\
\text { (alpine only); GW contribution } \\
\text { decreases with elevation; GW } \\
\text { recharge shows a non-linear } \\
\text { response to precipitation recharge } \\
\text { with elevation; Correlation } \\
\text { between geoclimatic and source } \\
\text { water variability }\end{array}$ \\
\hline
\end{tabular}


Table 2: Meteorological and hydrological data. Discharge was not available for GG in 2010 and the GG air temperature records were incomplete in 2011 and 2012. Ppt is precipitation and doy is day of year.

\begin{tabular}{|c|c|c|c|c|c|c|c|c|c|}
\hline Location & Water Year & $\begin{array}{c}\text { Mean Annual } \\
\text { Air Temp } \\
\left({ }^{\circ} \mathrm{C}\right) \\
\end{array}$ & $\begin{array}{c}\text { Specific } \\
\text { Discharge } \\
(\mathrm{mm})\end{array}$ & $\begin{array}{c}\text { Specific } \\
\text { Ppt } \\
(\mathrm{mm})\end{array}$ & $\begin{array}{c}\text { March- } \\
\text { May Ppt } \\
(\mathrm{mm})\end{array}$ & $\begin{array}{c}\text { Annual } \\
\text { Percent } \\
\text { Snow }\end{array}$ & $\begin{array}{c}\text { Annual } \\
\text { Percent } \\
\text { Rain }\end{array}$ & $\begin{array}{c}\text { Annual } \\
\text { Percent } \\
\text { Mixed }\end{array}$ & $\begin{array}{c}\text { Max SWE } \\
(\mathrm{cm}) \\
(\mathrm{doy}) \\
\end{array}$ \\
\hline \multirow[t]{6}{*}{ GL4 } & 2010 & -2.4 & 1120 & 1431 & 481 & 86 & 12 & 2 & 79 (147) \\
\hline & 2011 & -4.6 & 1503 & 1732 & 776 & 93 & 6 & 1 & $170(158)$ \\
\hline & 2012 & -6.0 & 1132 & 1155 & 255 & 70 & 27 & 3 & $41(62)$ \\
\hline & Mean & -4.3 & 1252 & 1439 & 504 & 83 & 15 & 2 & 97 (115) \\
\hline & Std. Dev. & 1.8 & 218 & 288 & 261 & 12 & 11 & 1 & $66(65)$ \\
\hline & Uncertainty & $\mathbf{n} / \mathbf{a}$ & 188 & 50 & 18 & $\mathbf{n} / \mathbf{a}$ & $\mathbf{n} / \mathbf{a}$ & $\mathbf{n} / \mathbf{a}$ & $\mathbf{n} / \mathbf{a}$ \\
\hline \multirow[t]{6}{*}{$\mathrm{CC}$} & 2010 & 4.3 & 238 & 867 & 231 & 73 & 17 & 10 & $\begin{array}{c}\text { C1: } 38 \text { (139); } \\
\text { Soddie: } 94 \text { (140) }\end{array}$ \\
\hline & 2011 & 2.5 & 327 & 1186 & 271 & 69 & 23 & 8 & $\begin{array}{c}\text { C1: } 55 \text { (145); } \\
\text { Soddie: } 104(152)\end{array}$ \\
\hline & 2012 & 3.8 & 131 & 833 & 51 & 64 & 33 & 3 & $\begin{array}{c}\text { C1: } 29(39) ; \\
\text { Soddie: } 95 \text { (79) }\end{array}$ \\
\hline & Mean & 3.5 & 232 & 962 & 184 & 69 & 24 & 7 & $\begin{array}{c}\text { C1: } 41 \text { (108); } \\
\text { Soddie: } 98 \text { (124) }\end{array}$ \\
\hline & Std. Dev. & 0.9 & 98 & 195 & 117 & 5 & 8 & 4 & $\begin{array}{c}\text { C1: } 13 \text { (60); } \\
\text { Soddie: } 6 \text { (39) }\end{array}$ \\
\hline & Uncertainty & $\mathbf{n} / \mathbf{a}$ & 8 & 34 & 6 & $\mathbf{n} / \mathbf{a}$ & $\mathbf{n} / \mathbf{a}$ & $\mathbf{n} / \mathbf{a}$ & $\mathbf{n} / \mathbf{a}$ \\
\hline \multirow[t]{6}{*}{ GG } & 2010 & 6.6 & $\mathrm{n} / \mathrm{a}$ & 507 & 115 & 51 & 23 & 26 & $\begin{array}{c}\text { North: } 15(98) \text {; } \\
\text { South: } 8(56)\end{array}$ \\
\hline & 2011 & $\mathrm{n} / \mathrm{a}$ & 64 & 557 & 77 & 30 & 41 & 29 & $\begin{array}{l}\text { North: } 11(40) \text {; } \\
\text { South: } 8 \text { (40) }\end{array}$ \\
\hline & 2012 & $\mathrm{n} / \mathrm{a}$ & 43 & 471 & 16 & 38 & 54 & 8 & $\begin{array}{c}\text { North: } 14(61) ; \\
\text { South: } 9(61)\end{array}$ \\
\hline & Mean & 6.6 & 54 & 532 & 69 & 40 & 39 & 21 & $\begin{array}{c}\text { North: } 13(66) \\
\text { South: } 8 \text { (52) }\end{array}$ \\
\hline & Std. Dev. & $\mathbf{n} / \mathbf{a}$ & 15 & 43 & 50 & 11 & 27 & 11 & $\begin{array}{l}\text { North: } 2 \text { (29); } \\
\text { South: } 1 \text { (11) }\end{array}$ \\
\hline & Uncertainty & $\mathbf{n} / \mathbf{a}$ & 2 & 19 & 2 & $\mathbf{n} / \mathbf{a}$ & $\mathbf{n} / \mathbf{a}$ & $\mathbf{n} / \mathbf{a}$ & $\mathbf{n} / \mathbf{a}$ \\
\hline
\end{tabular}


Page 52 of 54 
Table 3: Relative contributions (\%) and uncertainty (presented as a range of percent contributions as defined in section 3.7) of each end-member to annual streamflow for each catchment.

\begin{tabular}{cccc}
\hline Location, Year & $\begin{array}{c}\text { End-member 1 }(\%) \\
\text { (uncertainty) }\end{array}$ & $\begin{array}{c}\text { End-member 2 }(\%) \\
\text { (uncertainty) }\end{array}$ & $\begin{array}{c}\text { End-member 3 (\%) } \\
\text { (uncertainty) }\end{array}$ \\
\hline GL4 & Snow & Groundwater & Talus \\
2010 & $64(56-71)$ & $22(13-29)$ & $14(6-26)$ \\
2011 & $65(58-72)$ & $21(12-28)$ & $14(7-26)$ \\
2012 & $53(34-69)$ & $13(7-19)$ & $34(20-54)$ \\
\hline CC & Snow & Groundwater & Rain \\
2010 & $60(54-71)$ & $31(25-33)$ & $10(4-13)$ \\
2011 & $69(62-82)$ & $23(16-26)$ & $8(2-11)$ \\
2012 & $45(41-55)$ & $39(34-41)$ & $16(11-18)$ \\
\hline GG & Snow & Groundwater & Rain \\
2011 & $56(39-62)$ & $24(23-24)$ & $21(14-37)$ \\
2012 & $35(24-46)$ & $32(31-33)$ & $33(22-44)$ \\
\hline
\end{tabular}


Table 4: Predicted versus measured concentrations for conservative tracers from each catchment. Units are in $\mu$ eqL $\mathrm{L}^{-1}$ or $\mu$ moles $\mathrm{L}^{-1}(\mathrm{Si})$ or $\%\left(\delta^{18} \mathrm{O}\right)$. The difference $(\%)$ between observed and predicted means was normalized by dividing the sums of the observed and predicted means.

\begin{tabular}{|c|c|c|c|c|c|c|c|c|}
\hline Site & Tracer & $\begin{array}{c}\text { Observed } \\
\text { means }\end{array}$ & $\begin{array}{l}\text { Predicted } \\
\text { means }\end{array}$ & $\begin{array}{l}\text { Percent } \\
\text { difference }\end{array}$ & Slope & $\begin{array}{c}\text { Y- } \\
\text { intercept }\end{array}$ & $R^{2}$ & $\begin{array}{c}\text { Pearson } \\
\text { correlation } \\
\text { coefficient }\end{array}$ \\
\hline & 106.1 & 110.9 & 4.3 & 1.08 & -3.73 & 0.97 & 0.96 \\
\hline \multicolumn{2}{|c|}{$\begin{array}{r}\mathrm{GL} 4 \mathrm{Ca}^{2+} \\
\mathrm{Mg}^{2+}\end{array}$} & 21.6 & 19.6 & 10.5 & 1.03 & -2.79 & 0.87 & 0.95 \\
\hline \multicolumn{2}{|c|}{$\mathrm{SO}_{4}^{2-}$} & 71.8 & 69.1 & 3.9 & 0.98 & -1.32 & 0.84 & 0.92 \\
\hline \multirow{2}{*}{\multicolumn{2}{|c|}{$\begin{array}{l}\text { ANC } \\
\delta^{18} \mathrm{O} \\
\end{array}$}} & 65.6 & 69.7 & 6.0 & 1.05 & 0.68 & 0.67 & 0.91 \\
\hline & & -15.8 & -15.7 & 1.2 & 0.62 & -5.81 & 0.87 & 0.93 \\
\hline \multirow[t]{6}{*}{$\overline{\mathrm{CC}}$} & $\mathrm{Ca}^{2+}$ & 124.2 & 133.9 & 7.2 & 0.97 & 13.4 & 0.90 & 0.99 \\
\hline & $\mathrm{Mg}^{2+}$ & 58.5 & 62.6 & 6.5 & 1.05 & 1.41 & 0.94 & 0.98 \\
\hline & ANC & 202.3 & 245.8 & 17.7 & 0.88 & 67.9 & 0.94 & 0.97 \\
\hline & $\mathrm{Na}^{+}$ & 84.1 & 73.5 & 14.4 & 0.82 & 4.24 & 0.86 & 0.93 \\
\hline & $\mathrm{Si}$ & 161.58 & 152.6 & 6.5 & 0.92 & 2.20 & 0.92 & 0.96 \\
\hline & $\delta^{18} \mathrm{O}$ & -17.3 & -17.5 & 0.9 & 1.03 & 0.39 & 0.99 & 0.97 \\
\hline \multirow{5}{*}{$\overline{\mathrm{GG}}$} & $\mathrm{Ca}^{2+}$ & 287.6 & 316.6 & 9.15 & 0.82 & 82.2 & 0.95 & 0.98 \\
\hline & $\mathrm{Mg}^{2+}$ & 221.8 & 263.6 & 15.8 & 1.09 & 22.3 & 0.97 & 0.98 \\
\hline & ANC & 506.9 & 703.0 & 27.9 & 0.77 & 313 & 0.93 & 0.97 \\
\hline & $\mathrm{Na}^{+}$ & 137.0 & 140.5 & 2.6 & 1.05 & -53.4 & 0.87 & 0.93 \\
\hline & $\delta^{18} \mathrm{O}$ & -15.7 & -15.3 & 2.6 & 0.98 & 0.04 & 0.99 & 0.99 \\
\hline
\end{tabular}

